\title{
The impact of dietary consistency on structural craniofacial components: Temporomandibular joint/condyle, condylar cartilage, alveolar bone and periodontal ligament. A systematic review and meta-analysis in experimental in vivo research
}

\author{
Scheidegger, Rolf ; Koletsi, Despina ; Eliades, Theodore
}

\begin{abstract}
OBJECTIVE The aim of this systematic review was to provide a comprehensive synthesis of available evidence evaluating the effect of dietary loading on temporomandibular joint/condyle, condylar cartilage, alveolar bone of the mandible and the periodontal ligament in healthy mice and rats. DESIGN Medline via PubMed, EMBASE and Open Grey databases were searched for published and unpublished literature. Search terms included "mandiblular condyle", "alveolar bone", "temporomandibular joint", "condylar cartilage", "periodontal ligament", "rat", "mice". After data extraction, risk of bias (SYRCLE) and reporting quality (ARRIVE) were assessed. Random effects meta-analyses were performed for the outcomes of interest where applicable. RESULTS A total of 33 relevant articles were considered in the systematic review, while only 6 studies were included in the quantitative synthesis. Risk of Bias in all studies was judged to be unclear to high overall, while reporting quality was suboptimal. Comparing soft to hard diet animals, significantly reduced anteroposterior condylar length (4 studies, weighted mean difference: $-0.40 \mathrm{~mm}$; $95 \% \mathrm{CI}:-0.47,-0.32 ; \mathrm{p}<0.001$ ) and width (4 studies, weighted mean difference: $-0.043 \mathrm{~mm} ; 95 \% \mathrm{CI}:-0.51,-0.36 ; \mathrm{p}<0.001)$ were found in rats. Decreased anteroposterior condylar dimensions were detected for mice as well (2 studies, weighted mean difference: $-0.049 ; 95 \%$ CI: $-0.56,-0.43 ; \mathrm{p}<$ 0.001). CONCLUSIONS Overall, there was strong evidence to suggest a significant effect of soft diet on reduced condylar dimensions in rodents; however, there is need for further high quality experimental studies to inform current knowledge on condylar cartilage, alveolar bone and periodontal ligament related outcomes.
\end{abstract}

DOI: https://doi.org/10.1016/j.archoralbio.2018.06.016

Posted at the Zurich Open Repository and Archive, University of Zurich ZORA URL: https://doi.org/10.5167/uzh-169356

Journal Article

Accepted Version

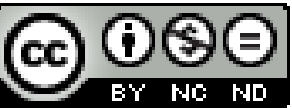

The following work is licensed under a Creative Commons: Attribution-NonCommercial-NoDerivatives 4.0 International (CC BY-NC-ND 4.0) License.

Originally published at:

Scheidegger, Rolf; Koletsi, Despina; Eliades, Theodore (2018). The impact of dietary consistency on structural craniofacial components: Temporomandibular joint/condyle, condylar cartilage, alveolar bone and periodontal ligament. A systematic review and meta-analysis in experimental in vivo research. Archives of Oral Biology, 94:33-47. 
DOI: https://doi.org/10.1016/j.archoralbio.2018.06.016 
The impact of dietary consistency on structural craniofacial components: temporomandibular joint/condyle, condylar cartilage, alveolar bone and periodontal ligament. A systematic review and meta-analysis in experimental in vivo research.

Rolf Scheidegger ${ }^{a}$ Despina Koletsi ${ }^{b, *}$, Theodore Eliades ${ }^{c}$

${ }^{a}$ Clinic of Orthodontics and Paediatric Dentistry, Center of Dental medicine, University of Zurich, Plattenstrasse 11, CH-8032 Zurich, Switzerland (Rolf.Ssheidegger@zzm.uzh.ch)

${ }^{\mathrm{b}} \mathrm{Clinic}$ of Orthodontics and Paediatric Dentistry, Center of Dental medicine, University of Zurich, Plattenstrasse 11, CH-8032 Zurich, Switzerland (d.koletsi@gmail.com)

${ }^{c}$ Clinic of Orthodontics and Paediatric Dentistry, Center of Dental medicine, University of Zurich, Plattenstrasse 11, CH-8032 Zurich, Switzerland (Theodore.Eliades@zzm.uzh.ch)

Publication: Scheidegger R, Koletsi D, Eliades T. The impact of dietary consistency on structural craniofacial components: Temporomandibular joint/condyle, condylar cartilage, alveolar bone and periodontal ligament. A systematic review and meta-analysis in experimental in vivo research. Arch Oral Biol. 2018;94:33-47.

Running Title: Dietary consistency and craniofacial components

*Corresponding author: Despina Koletsi, Plattenstrasse 11, Zurich 8032, Switzerland, email d.koletsi@gmail.com 
The impact of dietary consistency on structural craniofacial components: temporomandibular joint/condyle, condylar cartilage, alveolar bone and periodontal ligament. A systematic review and meta-analysis in experimental in vivo research. 


\section{Structured Abstract}

\section{Objective}

The aim of this systematic review was to provide a comprehensive synthesis of available evidence evaluating the effect of dietary loading on temporomandibular joint/condyle, condylar cartilage, alveolar bone of the mandible and the periodontal ligament in healthy mice and rats.

\section{Design}

Medline via PubMed, EMBASE and Open Grey databases were searched for published and unpublished literature. Search terms included "mandiblular condyle", "alveolar bone", "temporomandibular joint”, "condylar cartilage", "periodontal ligament”, "rat”, "mice”. After data extraction, risk of bias (SYRCLE) and reporting quality (ARRIVE) were assessed. Random effects meta-analyses were performed for the outcomes of interest where applicable.

\section{Results}

A total of 33 relevant articles were considered in the systematic review, while only 6 studies were included in the quantitative synthesis. Risk of Bias in all studies was judged to be unclear to high overall, while reporting quality was suboptimal. Comparing soft to hard diet animals, significantly reduced anteroposterior condylar length (4 studies, weighted mean difference: $-0.40 \mathrm{~mm}$; $95 \% \mathrm{Cl}:-0.47,-0.32 ; \mathrm{p}<0.001$ ) and width (4 studies, weighted mean difference: $-.043 \mathrm{~mm} ; 95 \% \mathrm{Cl}$ : $-0.51,-0.36 ; \mathrm{p}<0.001)$ were found in rats. Decreased anteroposterior condylar dimensions were detected for mice as well (2 studies, weighted mean difference: $-.049 ; 95 \% \mathrm{Cl}:-0.56,-0.43 ; \mathrm{p}<0.001)$.

\section{Conclusions}

Overall, there was strong evidence to suggest a significant effect of soft diet on reduced condylar dimensions in rodents; however, there is need for further high quality experimental studies to inform current knowledge on condylar cartilage, alveolar bone and periodontal ligament related outcomes.

Keywords: hard diet, soft diet, condyle, alveolar bone, periodontal ligament, craniofacial 


\section{Introduction}

During the course of human evolution, adaptations in human dental apparatus and craniofacial complex have taken place. Maxillary and mandibular bones have decreased in size, giving rise in tooth to alveolar bone discrepancies (Hanihara, Inoue, Ito, \& Kamegai, 1981; Shiono, Ito, Inuzuka, \& Hanihara, 1982) and increasing prevalence of malocclusions (Kelly \& Harvey, 1977). According to anthropologic data, this is a relatively recent phenomenon whereas a much lower incidence of malocclusions has been reported for "primitive" populations (Beyron, 1964; Hunt, 1961; Liu, 1977; Lombardi \& Bailit, 1972; Price, 1936; Wood, 1971). Notwithstanding, the form to function relationship of the jaws is genetically controlled and this has been demonstrated in inherited occlusal patterns pertaining within families (Kraus, Wise, \& Frei, 1959; Lundström, 1948) or in whole ethnic groups (Björk, 1947; Cotton, Takano, \& Wong, 1951; Craven, 1958); however not all phenotypic changes are due to the underlying genetic information. In early 1900s, the German anatomist and surgeon Wolff discovered that the internal architecture of femoral bone responds to external mechanical stress (Wolff, 2010). This constant adaptation of the trabecular bone can also be observed in the condylar process of the mandible and is ultimately based on variations in the level of activity of masticatory muscles.

In industrialized communities, life circumstances have changed dramatically with a subsequent impact on nutrition consistency. The dietary pattern has switched to "modern" processed diet which is softer and which goes along with a more limited use of the masticatory apparatus (Corruccini \& Lee, 1984; Waugh, 1937). The masticatory system itself is a complex neuro-musculoskeletal system constituting from different parts, containing the horseshoe-shaped lower jaw body (corpus mandibulae) that supports the alveolar bone process which houses the teeth and their surrounding periodontal ligament. The lower jaw as a whole is connected with the masticatory muscles and the temporomandibular joint (TMJ) 
to the rest of the skull. The TMJ has always been the center of research interest as it consists of the condylar process and cartilage which is a highly adaptive and respondent to mechanical stress tissue (Eames \& Schneider, 2008). As the force exerted on the TMJ is assumed to be greater during the mastication of hard food in contrast to softer diets (Boyd, Gibbs, Mahan, Richmond, \& Laskin, 1990), a change in food consistency would inevitably pose an effect on the structures of the craniofacial system.

Due to ethical reasons, experimental evidence in human is very difficult to prove; however, a number of parameters have been examined in laboratory animal models. Rodents and in particular mice and rats have been used for this purpose since they are easy to handle, inexpensive to maintain and show a close genetic background to human, making them a convenient animal model for use. Animal studies in general have shown a direct causal relationship between reduced masticatory muscle function and modified dietary consistency. Soft diet has been linked with alterations in the muscle fiber composition, decreased fiber diameter, reduced total muscle weight and reduced masticatory muscle strength, which in turn has a subsequent effect on the craniofacial complex especially in growing animals (Beecher \& Corruccini, 1981b; Kiliaridis, Engström, \& Thilander, 1988; Kiliaridis \& Shyu, 1988; Moore, 1965).

Although extensive animal studies have been published addressing the impact of dietary consistency upon both the hard and soft tissues, no systematic review has been performed in an attempt to place individual study conclusions into the appropriate context.

Therefore, the objective of this systematic review was to provide a comprehensive synthesis evaluating the effect of dietary loading on temporomandibular joint/condyle, condylar cartilage, alveolar bone of the mandible and the periodontal ligament in healthy mice or rats.

\section{Material and Methods}


The Preferred Reporting Items for Systematic Reviews and Meta-Analyses (Liberati et al., 2009; Moher, Liberati, Tetzlaff, \& Altman, 2009) were followed for reporting of this systematic review.

\subsection{Eligibility Criteria}

The following inclusion criteria were applied:

- Study design: Randomized or non-randomized experimental studies involving rodents were considered.

- Population/ Animal: Any laboratory strain of rat or mice at any age.

- Interventions: Soft diet administration for a given time period

- Comparators: Hard/Normal diet administration for a similar time period.

- Outcome measures: Effect of different type of dietary loading (ie soft/hard) on: 1.

Temporomandibular joint/condylar process , 2. Condylar Cartilage , 3. Alveolar bone of the mandible and 4. Periodontal ligament.

Exclusion Criteria:

- In vitro studies

- Animal studies without a comparison group

- Animal studies involving diet switching (from hard to soft and/or vice versa)

- Not healthy animal populations (ie, diabetic, ovariectomized etc)

- Animals being subject to other simultaneous interventions (ie incisor trimming, bite-blocks etc)

- Studies pertaining to molecular, genetic, biochemical outcomes.

\subsection{Search Strategy}

Electronic search within the following databases was undertaken in January 14, 2017, while no language restrictions were applied: Medline via Pubmed and EMBASE were searched. 
Moreover, unpublished literature was searched in Open Grey using the terms «diet» AND «rat OR mice». Hand searching of the reference lists of the retrieved full text articles was also conducted. Authors of original studies were contacted for data clarification if needed. Full search strategy implemented in Medline via Pubmed is presented in Appendix 1.

\subsection{Data Extraction}

Data extraction was performed on standardised piloted forms by one independently working reviewer (RS) and confirmed by a second (DK), both of whom were not blinded to author identity and study origin. Titles and abstracts were examined first, while at a second stage full text screening of the potential for inclusion articles was employed. Information was obtained from each included study on study design, population (type of animal), interventions, comparators and outcomes. In addition, information on duration of experiment and age of animals at the beginning of the active period of study was recorded. Any disagreements or ambiguity were resolved after consultation with a third author (TE).

\subsection{Reporting quality}

Reporting quality of the studies was assessed based on adherence to ARRIVE guidelines for reporting of animal studies (Kilkenny, Browne, Cuthill, Emerson, \& Altman, 2010). According to completeness of reporting, the reporting quality was judged as "clearly inadequate", "possibly inadequate" and "clearly adequate". A grading system of 20 items contributed to the overall judgement of reporting quality (Table 1).

\subsection{Risk of bias within studies}

Risk of bias (RoB) in individual studies was assessed in line with the SYstematic Review Centre for Laboratory animal Experimentation (SYRCLE) RoB tool for animal studies (Hooijmans et al., 2014). In particular, the following ten domains were considered: 1. 
Sequence generation, 2. Baseline characteristics, 3. Allocation concealment, 4. Random housing, 5. Blinding of researchers, 6 . Random outcome assessment, 7. Blinding of outcome assessors, 8. Incomplete outcome data, 9. Selective outcome reporting, 10. Other sources of bias.

An overall assessment of the risk of bias was made for each included study (high, unclear, low). Studies with at least 1 item designated to be at high risk of bias were regarded as having an overall high risk of bias. Reports with unclear risk of bias for one or more key domains were considered to be at unclear risk of bias and studies with low risk of bias in all domains were rated as low risk of bias.

\subsection{Summary Measures and Data Synthesis}

Clinical homogeneity of included studies was assessed through the examination of individual trial settings, eligibility criteria, interventions, experimental conditions, animal age and observation time. Statistical heterogeneity was examined through visual inspection of the confidence intervals (Cls) for the estimated treatment effects on forest plots. Also, a chisquare test was applied to assess heterogeneity; a $p$-value below the level of $10 \%(p<0.1)$ was considered indicative of significant heterogeneity (Higgins, Thompson, Deeks, \& Altman, 2003). $I^{2}$ test for homogeneity was also undertaken to quantify the extent of heterogeneity.

Random effects meta-analyses were conducted as they were considered more appropriate to better approximate expected variations in studies' settings. Treatment effects were calculated through pooled weighted mean differences (WMD) in all outcome related parameters with associated 95\% Confidence Intervals (95\% Cls) and Prediction Intervals where applicable (at least 3 trials needed). 


\subsection{Risk of bias across studies}

If more than 10 studies were included in meta-analysis, publication bias was to be explored through standard funnel plots.

\subsection{Additional Analyses}

Sensitivity analyses were pre-specified to explore and isolate the effect of studies with low risk of bias on the overall treatment effect if both low and higher risk of bias studies were included.

\section{Results}

\subsection{Search Details}

The flow diagram of the study selection is presented in Figure 1. The electronic search identified 995 articles, while records of 20 articles were identified after hand searching of the included for full-text evaluation studies. After the review of the titles, the abstracts and the full text manuscripts 33 studies were considered eligible for inclusion in the review, while 6 were eligible for quantitative evaluation.

\subsection{Study design and location}

In 15 studies (Abed, Buschang, Taylor, \& Hinton, 2007; Bresin, Kiliaridis, \& Strid, 1999; Endo, Mizutani, Yasue, Senga, \& Ueda, 1998; Enomoto et al., 2014; Enomoto et al., 2010; Guerreiro et al., 2013; Hichijo et al., 2014; Hinton \& Carlson, 1986; Ikeda, Yonemitsu, Takei, Shibata, \& Ono, 2014; Kingsmill, Boyde, Davis, Howell, \& Rawlinson, 2010; Maki, Nishioka, Shioiri, Takahashi, \& Kimura, 2002; McFadden, McFadden, \& Precious, 1986; Shimizu et al., 2013; Tanaka et al., 2007; Vaid, Pradhan, \& Chakrabarti, 2002), the animals were randomly allocated to either hard or soft diet feeding group, although no details of the randomization procedure were reported. In the rest $(n=18)$ of the studies (Barber, Green, \& Cox, 1963; Beecher \& Corruccini, 1981a; Bouvier, 1988; Bouvier \& Hylander, 1984; Bouvier \& Zimny, 1987; Bresin, Johansson, \& Kiliaridis, 1994;Bresin, Kiliaridis, \& Strid, 1999; Ito, 
Mitani, \& Kim, 1988; Kiliaridis, Bresin, Holm, \& Strid, 1996; Mavropoulos, Odman, Ammann, \& Kiliaridis, 2010; Odman, Mavropoulos, \& Kiliaridis, 2008; Orajarvi, 2015; Orajarvi et al., 2011; Orajarvi et al., 2012; Stahl \& Dreizen, 1964; Tiilikainen, Raustia, \& Pirttiniemi, 2011; Watt \& Williams, 1951; Yamada \& Kimmel, 1991) no obvious randomization was done or allocation was implemented by convenience. The country of origin (according to corresponding author affiliation) of the studies were Japan (Endo et al., 1998; Enomoto et al., 2014; Enomoto et al., 2010; Hichijo et al., 2014; Ikeda et al., 2014; Ito et al., 1988; Maki et al., 2002; Shimizu et al., 2013; Tanaka et al., 2007; Yamada \& Kimmel, 1991), United States (Abed et al., 2007; Barber et al., 1963; Beecher \& Corruccini, 1981a; Bouvier, 1988; Bouvier \& Zimny, 1987; Hinton \& Carlson, 1986; Stahl \& Dreizen, 1964), Finland (Orajarvi, 2015; Orajarvi et al., 2011; Orajarvi et al., 2012; Tiilikainen et al., 2011), Sweden (Bresin, Johansson, \& Kiliaridis, 1994; Bresin, Kiliaridis, \& Strid, 1999; Kiliaridis et al., 1996; Odman et al., 2008), Canada (McFadden et al., 1986; Watt \& Williams, 1951), Switzerland (Kiliaridis, Thilander, Kjellberg, Topouzelis, \& Zafiriadis, 1999; Mavropoulos et al., 2010), Brazil (Guerreiro et al., 2013), India (Vaid et al., 2002), Puerto Rico (Bouvier \& Hylander, 1984) and United Kingdom (Kingsmill et al., 2010). In the subgroup of studies dealing with temporomandibular joint/condyle of rats (Barber et al., 1963; Beecher \& Corruccini, 1981a; Bouvier, 1988; Bouvier \& Hylander, 1984; Bouvier \& Zimny, 1987; Bresin, Kiliaridis, \& Strid, 1999; Endo et al., 1998; Guerreiro et al., 2013; Hinton \& Carlson, 1986; lkeda et al., 2014; Kiliaridis et al., 1996; Kiliaridis et al., 1999; Maki et al., 2002; McFadden et al., 1986; Odman et al., 2008; Tanaka et al., 2007; Vaid et al., 2002; Watt \& Williams, 1951; Yamada \& Kimmel, 1991) the sample size ranged from 3 to 30 for both the hard and the soft diet animals The sample size for rat condylar cartilage (Bouvier, 1988; Bouvier \& Hylander, 1984; Endo et al., 1998; Hichijo et al., 2014; Hinton \& Carlson, 1986; Ikeda et al., 2014; Kiliaridis et al., 1999; Orajarvi, 2015; Orajarvi et al., 2011; Orajarvi et al., 2012; Tiilikainen et 
al., 2011; Vaid et al., 2002; Yamada \& Kimmel, 1991) ranged from 3 to 16, while for the mandibular alveolar bone (Abed et al., 2007; Bresin, Kiliaridis, \& Strid, 1999; Kiliaridis et al., 1996; Kingsmill et al., 2010; Mavropoulos et al., 2010; Odman et al., 2008; Shimizu et al., 2013; Tanaka et al., 2007; Watt \& Williams, 1951; Yamada \& Kimmel, 1991), six to 30 animals were recruited. As for the rat periodontal ligament outcome (Bresin, Kiliaridis, \& Strid, 1999; Stahl \& Dreizen, 1964), thirteen to fourteen animals were used.

In the subgroup of the mouse temporomandibular joint/condyle (Enomoto et al., 2010; Ito et al., 1988) the sample size ranged from 5 to 20 . One study with results pertaining to mouse condylar cartilage was found (Enomoto et al., 2014), consisting of 5 animals in each group. There were no results of interest regarding either the mandibular alveolar bone or the periodontal ligament.

\subsection{Animal Population}

A total number of 33 studies were included in the review. Thirty studies using rat populations with a total number of 833 animals were considered (250 females and 583 males). Male rats were used in 18 studies (Abed et al., 2007; Barber et al., 1963; Bouvier \& Hylander, 1984; Bresin, Johansson, \& Kiliaridis, 1994; Bresin, Kiliaridis, \& Strid, 1999; Endo et al., 1998; Guerreiro et al., 2013; Hichijo et al., 2014; Hinton \& Carlson, 1986; Ikeda et al., 2014; Kiliaridis et al., 1996; Kiliaridis et al., 1999; Maki et al., 2002; Mavropoulos et al., 2010; Odman et al., 2008; Shimizu et al., 2013; Stahl \& Dreizen, 1964; Tanaka et al., 2007), female in 6 (Kingsmill et al., 2010; Orajarvi, 2015; Orajarvi et al., 2011; Orajarvi et al., 2012; Tiilikainen et al., 2011; Yamada \& Kimmel, 1991) while 6 studies used both sexes (Beecher \& Corruccini, 1981a; Bouvier, 1988; Bouvier \& Zimny, 1987; McFadden et al., 1986; Vaid et al., 2002; Watt \& Williams, 1951). The age at the beginning of the intervention ranged from 2 weeks to 4 months for the rat species, while most of the studies used 3 week old animals $(63,3 \%)$ (Table 2$)$. In addition, three studies dealing with mice (Enomoto et al., 
2014; Enomoto et al., 2010; Ito et al., 1988), consisting of a total number of 240 animals (all males) were considered. The starting age for these species ranged from 2 to 3 weeks (Table 3).

\subsection{Interventions and observation period}

Rats

The observation period for the subgroups of separate outcomes ranged as follows: for the temporomandibular joint/condyle from 26 days to 27 weeks, for the condylar cartilage from 7 days to 17 weeks, for the mandibular alveolar bone from 4 weeks to 27 weeks and for the molar periodontal ligament from 4 weeks up to 66 weeks (Table 2).

Mice

The observation period regarding temporomandibular joint/condyle ranged from 1 week to 18 weeks while for the condylar cartilage from 1 week to 4 weeks respectively. There were no results for the mouse mandibular alveolar bone or the molar periodontal ligament (Table $3)$.

\subsection{Outcomes}

The four parameters of interest were evaluated for rats and mice independently and subdivided in different subgroups.

Rats (Table 2)

1. Temporomandibular joint/condylar process:

- X- ray findings

- Histologic/histomorphometric findings

- Condyle length measurements (either anteroposterior length or length of the condyle process perpendicular to a tangent to the notches)

- Condyle width measurement 
- Area of condylar process measurement

2. Condylar Cartilage:

- Thickness of condylar cartilage (histologic zones)

- Condylar cartilage depth

3. Alveolar bone of the mandible:

- X- ray findings

- Height of molar alveolar bone

- Width of molar alveolar bone

4. Periodontal ligament:

- Width of periodontal space

\section{Mice (Table 3)}

1. Temporomandibular joint/condylar process:

- Condyle length measurement

- Condyle width measurement

2. Condylar Cartilage in general

\subsection{Reporting Quality of Included Studies}

According to the ARRIVE guidelines (Table 1), information on title was adequate in general although some studies did not define species or used a rather general title (Figure 2). The abstract was adequate as well, with the exception of some older studies (Barber et al., 1963; Beecher \& Corruccini, 1981a; Stahl \& Dreizen, 1964; Watt \& Williams, 1951), where no obvious abstract was available. All but one (Barber et al., 1963) study showed a sufficient background and an adequate description of the study objectives. Only a limited number of studies (Guerreiro et al., 2013; Ikeda et al., 2014; Shimizu et al., 2013) showed complete data regarding ethical statement, some did not report a relevant approval, while 
more than half reported no information. In general there was an overall moderate reporting quality (ie rated as possibly inadequate) regarding study design and no study reported a clear randomization process. A few studies (18.2\%) reported blinding when assessing the results while some provided details of the experimental unit. Overall information regarding experimental procedures was adequate. Regarding the experimental animals, available information was adequate with few exceptions (Beecher \& Corruccini, 1981a; Orajarvi, 2015; Orajarvi et al., 2011; Orajarvi et al., 2012; Yamada \& Kimmel, 1991) whereas information regarding housing and husbandry was not clearly reported. No study provided information on sample size calculation while in a few the number of animals in each experimental group was unclear (Beecher \& Corruccini, 1981a; Bouvier \& Zimny, 1987; Endo et al., 1998; Hinton \& Carlson, 1986; Ito et al., 1988). All but one study (Barber et al., 1963) reported a detailed outcome evaluation procedure, presented information on statistical analysis (with exception of (Hinton \& Carlson, 1986; Ito et al., 1988; Stahl \& Dreizen, 1964) and provided baseline data regarding weight prior to testing. Very few studies reported on missing data in each group under evaluation, presented their results with a measure of precision or dealt with information on possible adverse effects. None of the studies referred to the "3 R" $s$ " principle (replacement, refinement and reduction) for experimental animals (Kilkenny et al. 2010), whereas most considered relevance to human biology in the discussion. Funding statement was clearly inadequate or clearly adequate on equal parts (Figure 2).

\subsection{Risk of Bias of Included Studies}

In 15 studies (45.5\%) the animals were "randomly" allocated to different feeding protocols, although no details of the randomization process or allocation concealment were reported (see Figures 3 and 4). Baseline characteristics were almost clearly described. Blinding of the caregivers was rated as unclear as although it was most probably difficult to be 
implemented given the nature of the intervention, the effect of absence of blinding cannot be disregarded. There were no details regarding the random selection of the animals for outcome assessment. Six studies (18.2\%) reported blinding of the outcome assessor to minimize "detection bias." In the majority of studies it was not clear whether all animals were included in the analyses. Only 5 (15.2\%) reported the analyzed number of animals or provided reasoning for missing data. Almost 60 percent of the studies were free from selective outcome reporting providing adequate addressing of the pre-defined outcomes, while 12 studies (36.4\%) achieved an unclear rating. Lastly, missing information regarding animal weight at the initiation of the experiments was rated high risk of bias, as this was considered a significant factor contributing to analysis errors since linear dimensions are increased in heavier animals. Overall, eleven studies were identified with missing weight data. An unclear distribution of male and female animals between the intervention groups was classified as another potential source of bias due to sexual dimorphism and was detected in two studies (Beecher \& Corruccini, 1981a; Vaid et al., 2002) (Figure 3, Figure 4).

\subsection{Effects of interventions, meta-analyses and additional analyses}

In the light of the available data, only three syntheses were possible for either rats or mice populations, all pertaining to alterations in condylar dimensions following soft and hard diet. According the results of random effects meta-analysis regarding anteroposterior condylar length in rat populations, there was strong evidence of significantly reduced length for rats receiving soft diet as compared to those receiving hard (4 studies, weighted mean difference: $-0.40 \mathrm{~mm} ; 95 \% \mathrm{Cl}:-0.47,-0.32 ; p<0.001 ; \mathrm{l}^{2}=0.0 \%, p=0.74$; Figure 5$)$. A similar finding was detected when condylar width dimensions were examined (4 studies, weighted mean difference: $-.043 \mathrm{~mm} ; 95 \% \mathrm{Cl}:-0.51,-0.36 ; p<0.001 ; \mathrm{l}^{2}=46.7 \%, p=0.13$; Figure 6$)$. 
In mice populations, there was strong evidence in favour of significantly smaller condylar length in soft diet groups (2 studies, weighted mean difference: -.049; $95 \% \mathrm{Cl}:-0.56,-0.43$; $p<0.001 ; l^{2}=0.0 \%, p=0.87 ;$ Figure 7 ).

\subsection{Risk of Bias across studies}

Exploring for publication bias either statistically or graphically was not undertaken as no more than 4 studies were included in any individual synthesis.

\subsection{Summary of main results}

\section{Rats (Table 2)}

Temporomandibular joint/condylar process

- X- ray findings:

Six studies (Bresin, Kiliaridis, \& Strid, 1999; Ikeda et al., 2014; Maki et al., 2002; Tanaka et al., 2007; Watt \& Williams, 1951) assessed temporomandibular joint/condylar process on xrays with five heterogeneous measurement techniques. Initial animal age ranged from three to 4 weeks and observation period from four to 16 weeks. In general, bone showed increased mass/density and higher degree of mineralization in animals fed with hard diet - Histologic/histomorphometric findings:

Histologic/histomorphometric investigation of the temporomandibular joint/condylar process process took place in four studies (Bouvier, 1988; Bouvier \& Hylander, 1984; Hinton \& Carlson, 1986; Yamada \& Kimmel, 1991). Age at the beginning ranged from 3 weeks to 4 months and observational period lasted from 26 days to 12 weeks. Overall reduced quantity/volume of subchondral bone due to reduced density and size of trabeculae was recorded in soft diet rats.

- Condyle process length, width and area measurement: 
Condyle process length measurements were performed in 11 studies (Barber et al., 1963; Beecher \& Corruccini, 1981a; Bouvier, 1988; Bouvier \& Hylander, 1984; Bouvier \& Zimny, 1987; Endo et al., 1998; Guerreiro et al., 2013; Kiliaridis et al., 1999; McFadden et al., 1986; Odman et al., 2008; Vaid et al., 2002), while condylar process width was measured in 6 studies (Bouvier, 1988; Bouvier \& Hylander, 1984; Bouvier \& Zimny, 1987; Endo et al., 1998; Kiliaridis et al., 1999; Vaid et al., 2002) and condylar process area in two (Barber et al., 1963; Odman et al., 2008). Age at the beginning of the intervention ranged from 2 weeks to 4 months for animals measuring length and width and from 3 to 27 weeks for area measurement respectively. After a period of 4 to 27 weeks using differential diet consumption, increased condylar dimensions were observed in animals fed with hard diet. Condylar Cartilage

A total number of 13 studies (Bouvier, 1988; Bouvier \& Hylander, 1984; Endo et al., 1998; Hichijo et al., 2014; Hinton \& Carlson, 1986; Ikeda et al., 2014; Kiliaridis et al., 1999; Orajarvi, 2015; Orajarvi et al., 2011; Orajarvi et al., 2012; Tiilikainen et al., 2011; Vaid et al., 2002; Yamada \& Kimmel, 1991) assessed condylar cartilage on histologic sections in all three planes of space. Initial age was three weeks for most studies but ranged from two weeks up to 4 months while the range for the observational period was 2 to 17 weeks. All cartilage zones (articular, proliferative, chondroblastic and hypertrophic) were found to be affected by alterations in diet, with soft diet animals presenting thinner cartilage layers in general. In addition, hard diet animals showed a further increase in the maximum depth of the condylar cartilage when dry condyles were assessed (Bouvier \& Hylander, 1984; Vaid et al., 2002).

Molar alveolar bone of the mandible - X- ray findings: 
Six studies ( Bresin, Kiliaridis, \& Strid, 1999; Kiliaridis et al., 1996; Kingsmill et al., 2010; Mavropoulos et al., 2010; Shimizu et al., 2013; Tanaka et al., 2007) analyzed molar alveolar bone of the mandible - most in the region of the first molar tooth, on x-rays with heterogeneous measurement techniques. Bone sections were examined after an experimental period ranging from 4 to 27 weeks. Bone mass/density and common micro-CT parameters such as ratio bone volume/trabecular volume, trabecular thickness, trabecular number, trabecular spacing width, trabecular volume and connectivity density were found to increase in hard diet animals (Mavropoulos et al., 2010; Shimizu et al., 2013), while other micro - CT parameters such as marrow space, trabecular spacing and bone surface/bone volume ratio decreased (Odman et al., 2008; Shimizu et al., 2013).

- Height and width of molar alveolar bone:

The use of three heterogeneous investigation methods (micro-CT, lateral photographs of dry hemimandibles and lateral cephalograms) for measuring height (Bresin, Johansson, \& Kiliaridis, 1994; Mavropoulos et al., 2010; Odman et al., 2008) as well as three methods for measuring width (micro- CT, dry mandible and contact micro-radiograms) (Bresin, Johansson, \& Kiliaridis, 1994 ; Mavropoulos et al., 2010; Watt \& Williams, 1951) of alveolar bone in the first molar region, revealed an overall increase in both dimensions in hard diet animals (initial age: 3-29 days; observation period: 4-27 weeks).

Molar periodontal ligament

- Width of periodontal space:

Two studies (Bresin, Johansson, \& Kiliaridis, 1994; Stahl \& Dreizen, 1964) with quite similar initial age (4 to 5 weeks) reported increased periodontal space on histological sections in either mesio- distal or in bucco- lingual direction in hard diet animals.

Mice (Table 3) 
Three studies (Enomoto et al., 2014; Enomoto et al., 2010; Ito et al., 1988) assessed the temporomandibular joint/condylar process through measuring the condyle length and width (initial age: 2-3 weeks, observation period: 1-18 weeks). Condylar width (Enomoto et al., 2010) dimensions on micro-CT as well as condylar length on lateral x-rays were found to increase in hard diet animals. Regarding cartilage on histologic sections, one study (Enomoto et al., 2014) using 3 week old animals found a thicker hypertrophic zone in hard diet animals after feeding the different diets for 1 to 4 weeks.

\section{Discussion}

The present study aimed to systematically assess the evidence on the effect of food consistency (hard/soft diet) on four structural craniofacial components in healthy rodents, namely (1) the temporomandibular joint/condyle, (2) the condylar cartilage, (3) the molar alveolar bone and (4) the molar periodontal ligament. The use of experimental animals in research has led to societal debates due to ethical questions arising in conjunction to laboratory animal suffering for an expected/potential benefit to humans (de Vries et al., 2014). A weak design, conduct and analysis of scientific studies related to laboratory animals is likely to produce unreliable results and may lead to both research waste and animal waste (loannidis et al., 2014). An optimization of the above mentioned research procedures for future experimental animal studies may be reached through gathering of the available evidence and identifying knowledge gaps and current study limitations with the aid of systematic reviews and meta-analysis of previously performed experiments (de Vries et al., 2014; Hooijmans et al., 2014). Up to now, there is no known previous systematic review investigating the effect of dietary consistency on craniofacial components in rodents although there is a breadth of individual animal studies. 
Rodents play a critical role in research, making up the largest part of all laboratory animals. The reasons for their choice may be considered rather clear: they are small, can easily be housed and maintained and do have a short lifespan (Gomes \& Fernandes, 2011). An additional reason is their well-known genetic background that closely resembles those of human. Identifying the effect of food consistency on phenotypic variation in human populations is difficult. Genetic, developmental and environmental sources of variance interact, which in contrast can be better controlled when using laboratory animals for research purposes.

In the present meta-analysis, only a limited number of studies contributed to the polled estimated effect for condylar dimensions in both rats and mice. Overall, a significantly larger condylar process in terms of length and width was recorded for rats that received a hard diet as compared to those that were fed with soft diet. A similar conclusion was reached for mice. Experimental period typically allowed for a relatively short observation period of a month in growing animals.

Condylar cartilage (secondary cartilage) is a very heterogeneous tissue containing cells at various stages of chondrogenic maturation. The terminology and classification differed between the investigators, while it largely depends on animal species as well as growth stage of the tissue (Mizoguchi, Toriya, \& Nakao, 2013). Most authors found an impact of either soft or hard diet on individual cartilage layers; however, meta-analysis was not possible due to large heterogeneity in the origin of the related measurements, and the localization and orientation of the sections used for histologic evaluation. Regarding molar alveolar bone of the mandible, an overall increased height and width was identified for the hard diet animals. Likewise, the heterogeneous investigation methods used for linear 
measurements were not compatible with data synthesis. Evidence assessing molar periodontal ligament was rather scarce to allow for a definite assessment.

The SYRCLE tool (Hooijmans et al., 2014) was used to assess the internal validity and evaluate the risk of bias within original studies. The overall quality of the considered studies was found to be low with related inherent unclear to high risk of bias. Selection bias was one of the main reporting shortcomings as no study reported details of randomization when assigning treatment alternatives. In addition to selection bias, detection bias cannot be overruled as it was unclear whether outcome raters of individual studies were blinded, irrespective of the nature of the outcome. This may reveal significant flaws in the design and reporting of animal studies which in turn may bear an effect on laboratory research waste. The SYRCLE risk of bias tool used in this systematic review was a first step towards transparency in the reporting of diet related rodent studies that will hopefully assist in improving design, conduct and analysis of future work.

The ARRIVE guidelines have been developed in 2010 (Kilkenny et al., 2010) in an attempt to improve reporting of animal research in general and have been used within the scopes of the present review in order to identify the reporting quality of the included articles. This approach has highlighted the need for improved and more standardised reporting as far as characteristics of animal populations involved in the experimental procedures are concerned. Although ARRIVE guidelines have been used in experimental research in other fields of dentistry (Berglundh \& Stavropoulos, 2012), it seems that adherence to these standards remains suboptimal with regard to research in food dietary consistency and craniofacial structures.

In the present review, only studies with solid intervention schemes with the use of either soft or hard diet in isolation were considered. Studies with switching diet groups handled by 
cross- over type designs were excluded. The main reason for this was our intention to capture the net intervention effects on each of the four structures of the mandible, whilst confining the apparent carry- over effects of potential alternate interventions.

The main characteristic of the available evidence was the lack of consistency and the high level of heterogeneity in the methodologies followed in individual studies. This reflected not only differences in experimental settings but also lack of homogeneity in the age of animal populations, the duration of the experimental period as well as the outcome measures and means of evaluation considered. Apparently, there is an overriding need for standardization of procedures followed both at the stage of protocol development but also during the phase of outcome assessment. The development of core outcomes has been proposed in clinical research (Tsichlaki et al., 2017) and should be applicable in experimental research as well in an attempt to provide a live basis upon which the available evidence and gathered data would be synthesized and compared.

\section{Conclusions}

1. Overall, based on studies of unclear to high risk of bias, rats receiving a soft diet at an initial age of 3 to 4 weeks presented smaller condylar width and anteroposterior length dimensions after an experimental period of 4 to 5 weeks. In soft diet mice (initial age 2-3 weeks), a decreased condylar length was observed as well after 4 to 5 weeks experimental period.

2. Data synthesis with regard to condylar cartilage and alveolar bone was not possible due to heterogeneous measurement techniques and origins of analysis. In the case of periodontal ligament, evidence was very scarce.

3. A standardization of the experimental protocols and the intervention procedures is recommended, to prevent animal and research waste. 
Funding: This research did not receive any grant from funding agencies in the public, commercial, or not-for-profit sectors.

Competing interests: The authors declare that they have no competing interests. 


\section{References}

Abed, G. S., Buschang, P. H., Taylor, R., \& Hinton, R. J. (2007). Maturational and functional related differences in rat craniofacial growth. Archives of Oral Biology, 52(11), 10181025. doi:10.1016/j.archoralbio.2007.05.008

Barber, C. G., Green, L. J., \& Cox, G. J. (1963). Effects of the physical consistency of diet on the condylar growth of the rat mandible. Journal of Dental Research, 42, 848-851. doi:10.1177/00220345630420031601

Beecher, R. M., \& Corruccini, R. S. (1981a). Effects of dietary consistency on craniofacial and occlusal development in the rat. Angle Orthodontist, 51(1), 61-69. doi:10.1043/0003-3219(1981)051<0061:eodcoc>2.0.co;2

Beecher, R. M., \& Corruccini, R. S. (1981b). Effects of dietary consistency on maxillary arch breadth in macaques. Journal of Dental Research, 60(1), 68. doi:10.1177/00220345810600011301

Berglundh, T., \& Stavropoulos, A. (2012). Preclinical in vivo research in implant dentistry. Consensus of the eighth European workshop on periodontology. Journal of Clinical Periodontology, 39 Suppl 12, 1-5. doi:10.1111/j.1600-051X.2011.01827.x

Beyron, H. (1964). Occlusal relations and mastication in australian aborigines. Acta Odontologica Scandinavica, 22, 597-678.

Björk, A. (1947). The Face in Profile. An Anthropological X-ray Investigation on Swedish Children and Conscripts. By Arne Björk. Akad. Avh.

Bouvier, M. (1988). Effects of age on the ability of the rat temporomandibular joint to respond to changing functional demands. Journal of Dental Research, 67(9), 12061212. doi: $10.1177 / 00220345880670091101$

Bouvier, M., \& Hylander, W. L. (1984). The effect of dietary consistency on gross and histologic morphology in the craniofacial region of young rats. American Journal of Anatomy, 170(1), 117-126. doi:10.1002/aja.1001700109

Bouvier, M., \& Zimny, M. L. (1987). Effects of mechanical loads on surface morphology of the condylar cartilage of the mandible in rats. Acta Anatomy (Basel), 129(4), 293300.

Boyd, R. L., Gibbs, C. H., Mahan, P. E., Richmond, A. F., \& Laskin, J. L. (1990). Temporomandibular joint forces measured at the condyle of Macaca arctoides. American Journal of Orthodontics and Dentofacial Orthopedics, 97(6), 472-479. doi:10.1016/s0889-5406(05)80027-7

Bresin, A., Johansson, C. B., \& Kiliaridis, S. (1994). Effects of occlusal strain on the development of the dentoalveolar process in the growing rat: A morphometric study. European Journal of Experimental Musculoskeletal Research, 3, 112-122.

Bresin, A., Kiliaridis, S., \& Strid, K. G. (1999). Effect of masticatory function on the internal bone structure in the mandible of the growing rat. European Journal of Oral Sciences, 107(1), 35-44.

Corruccini, R. S., \& Lee, G. T. (1984). Occlusal variation in Chinese immigrants to the United Kingdom and their offspring. Archives of Oral Biology, 29(10), 779-782.

Cotton, W. N., Takano, W. S., \& Wong, W. M. (1951). The Downs analysis applied to three other ethnic groups. Angle Orthodontist, 21(4), 213-220. doi:10.1043/00033219(1951)021<0213:tdaatt>2.0.co;2

Craven, A. H. (1958). A Radiographic Cephalometric Study of the Central Australian Aboriginal*. Angle Orthodontist, 28(1), 12-35. doi:10.1043/00033219(1958)028<0012:arcsot>2.0.co;2 
de Vries, R. B., Wever, K. E., Avey, M. T., Stephens, M. L., Sena, E. S., \& Leenaars, M. (2014). The usefulness of systematic reviews of animal experiments for the design of preclinical and clinical studies. Ilar Journal, 55(3), 427-437. doi:10.1093/ilar/ilu043

Eames, B. F., \& Schneider, R. A. (2008). The genesis of cartilage size and shape during development and evolution. Development, 135(23), 3947-3958.

doi:10.1242/dev.023309

Endo, Y., Mizutani, H., Yasue, K., Senga, K., \& Ueda, M. (1998). Influence of food consistency and dental extractions on the rat mandibular condyle: a morphological, histological and immunohistochemical study. Journal of Craniomaxillofacial Surgery, 26(3), 185-190.

Enomoto, A., Watahiki, J., Nampo, T., Irie, T., Ichikawa, Y., Tachikawa, T., \& Maki, K. (2014). Mastication markedly affects mandibular condylar cartilage growth, gene expression, and morphology. American Journal of Orthodontics and Dentofacial Orthopedics, 146(3), 355-363. doi:10.1016/j.ajodo.2014.05.028

Enomoto, A., Watahiki, J., Yamaguchi, T., Irie, T., Tachikawa, T., \& Maki, K. (2010). Effects of mastication on mandibular growth evaluated by microcomputed tomography.

European Journal of Orthodontics, 32(1), 66-70. doi:10.1093/ejo/cjp060

Gomes, P. S., \& Fernandes, M. H. (2011). Rodent models in bone-related research: the relevance of calvarial defects in the assessment of bone regeneration strategies. Laboratory Animals, 45(1), 14-24. doi:10.1258/la.2010.010085

Guerreiro, F. d. S., Diniz, P., Carvalho, P. E. G., Ferreira, E. C., Avancini, S. R. P., \& Ferreira-Santos, R. I. (2013). Effects of masticatory hypofunction on mandibular morphology, mineral density and basal bone area. Brazilian Journal of Oral Sciences, 12, 205-211.

Hanihara, K., Inoue, N., Ito, G., \& Kamegai, T. (1981). Microevolution and Tooth to Denture Base Discrepancy in Japanese Dentition. Journal of the Anthropological Society of Nippon, 89(1), 63-70. doi:10.1537/ase1911.89.63

Hichijo, N., Kawai, N., Mori, H., Sano, R., Ohnuki, Y., Okumura, S., . . Tanaka, E. (2014). Effects of the masticatory demand on the rat mandibular development. Journal of Oral Rehabilitation, 41(8), 581-587. doi:10.1111/joor.12171

Higgins, J. P., Thompson, S. G., Deeks, J. J., \& Altman, D. G. (2003). Measuring inconsistency in meta-analyses. British Medical Journal, 327(7414), 557-560. doi:10.1136/bmj.327.7414.557

Hinton, R. J., \& Carlson, D. S. (1986). Response of the mandibular joint to loss of incisal function in the rat. Acta Anatomy (Basel), 125(3), 145-151.

Hooijmans, C. R., Rovers, M. M., de Vries, R. B. M., Leenaars, M., Ritskes-Hoitinga, M., \& Langendam, M. W. (2014). SYRCLE's risk of bias tool for animal studies. BMC Medical Research Methodology, 14(1), 43. doi:10.1186/1471-2288-14-43

Hunt, E. E., Jr. (1961). Malocclusion and civilization. American Journal of Orthodontics, 47, 406-422.

Ikeda, Y., Yonemitsu, I., Takei, M., Shibata, S., \& Ono, T. (2014). Mechanical loading leads to osteoarthritis-like changes in the hypofunctional temporomandibular joint in rats. Archives of Oral Biology, 59(12), 1368-1376. doi:10.1016/j.archoralbio.2014.08.010

Ioannidis, J. P., Greenland, S., Hlatky, M. A., Khoury, M. J., Macleod, M. R., Moher, D., . . . Tibshirani, R. (2014). Increasing value and reducing waste in research design, conduct, and analysis. Lancet, 383(9912), 166-175. doi:10.1016/s01406736(13)62227-8

Ito, G., Mitani, S., \& Kim, J. H. (1988). Effect of soft diets on craniofacial growth in mice. Anatomischer Anzeiger, 165(2-3), 151-166. 
Kelly, J. E., \& Harvey, C. R. (1977). An assessment of the occlusion of the teeth of youths 12-17 years. Vital Health Statistics 11(162), 1-65.

Kiliaridis, S., Bresin, A., Holm, J., \& Strid, K. G. (1996). Effects of masticatory muscle function on bone mass in the mandible of the growing rat. Acta Anatomy (Basel), 155(3), 200-205.

Kiliaridis, S., Engström, C., \& Thilander, B. (1988). Histochemical analysis of masticatory muscle in the growing rat after prolonged alteration in the consistency of the diet. Archives of Oral Biology, 33(3), 187-193. doi:https://doi.org/10.1016/00039969(88)90044-1

Kiliaridis, S., \& Shyu, B. C. (1988). Isometric muscle tension generated by masseter stimulation after prolonged alteration of the consistency of the diet fed to growing rats. Archives of Oral Biology, 33(7), 467-472.

Kiliaridis, S., Thilander, B., Kjellberg, H., Topouzelis, N., \& Zafiriadis, A. (1999). Effect of low masticatory function on condylar growth: a morphometric study in the rat. American Journal of Orthodontics and Dentofacial Orthopedics, 116(2), 121-125.

Kilkenny, C., Browne, W. J., Cuthill, I. C., Emerson, M., \& Altman, D. G. (2010). Improving bioscience research reporting: the ARRIVE guidelines for reporting animal research. PLoS Biology, 8(6), e1000412. doi:10.1371/journal.pbio.1000412

Kingsmill, V. J., Boyde, A., Davis, G. R., Howell, P. G., \& Rawlinson, S. C. (2010). Changes in bone mineral and matrix in response to a soft diet. Journal of Dental Research, 89(5), 510-514. doi:10.1177/0022034510362970

Kraus, B. S., Wise, W. J., \& Frei, R. H. (1959). Heredity and the craniofacial complex. American Journal of Orthodontics, 45(3), 172-217. doi:https://doi.org/10.1016/00029416(59)90076-4

Liberati, A., Altman, D. G., Tetzlaff, J., Mulrow, C., Gotzsche, P. C., loannidis, J. P., .. . Moher, D. (2009). The PRISMA statement for reporting systematic reviews and meta-analyses of studies that evaluate healthcare interventions: explanation and elaboration. British Medical Journal, 339, b2700. doi:10.1136/bmj.b2700

Liu, K. L. (1977). Dental condition of two tribes of Taiwan aborigines--Ami and Atayal. Journal of Dental Research, 56(2), 117-127. doi:10.1177/00220345770560020401

Lombardi, A. V., \& Bailit, H. L. (1972). Malocclusion in the Kwaio, a Melanesian group on Malaita, Solomon Islands. American Journal of Physical Anthropology, 36(2), 283293. doi:10.1002/ajpa.1330360216

Lundström, A. (1948). Tooth size and occlusion in twins: S. Karger.

Maki, K., Nishioka, T., Shioiri, E., Takahashi, T., \& Kimura, M. (2002). Effects of dietary consistency on the mandible of rats at the growth stage: computed X-ray densitometric and cephalometric analysis. Angle Orthodontist, 72(5), 468-475. doi:10.1043/0003-3219(2002)072<0468:eodcot>2.0.co;2

Mavropoulos, A., Odman, A., Ammann, P., \& Kiliaridis, S. (2010). Rehabilitation of masticatory function improves the alveolar bone architecture of the mandible in adult rats. Bone, 47(3), 687-692. doi:10.1016/j.bone.2010.06.025

McFadden, L. R., McFadden, K. D., \& Precious, D. S. (1986). Effect of controlled dietary consistency and cage environment on the rat mandibular growth. The Anatomical Record, 215(4), 390-396. doi:10.1002/ar.1092150409

Mizoguchi, I., Toriya, N., \& Nakao, Y. (2013). Growth of the mandible and biological characteristics of the mandibular condylar cartilage. Japanese Dental Science Review, 49(4), 139-150. doi:https://doi.org/10.1016/j.jdsr.2013.07.004

Moher, D., Liberati, A., Tetzlaff, J., \& Altman, D. G. (2009). Preferred reporting items for systematic reviews and meta-analyses: the PRISMA statement. Journal of Clinical Epidemiology, 62(10), 1006-1012. doi:10.1016/j.jclinepi.2009.06.005 
Moore, W. J. (1965). Masticatory function and skull growth. Proceedings of the Zoological Society of London, 146(2), 123-131. doi:10.1111/j.1469-7998.1965.tb05205.x

Odman, A., Mavropoulos, A., \& Kiliaridis, S. (2008). Do masticatory functional changes influence the mandibular morphology in adult rats. Archives of Oral Biology, 53(12), 1149-1154. doi:10.1016/j.archoralbio.2008.07.004

Orajarvi, M. (2015). Effect of estrogen and dietary loading on rat condylar cartilage. University of Oulu, Oulu Finland.

Orajarvi, M., Hirvonen, O., Yu, S. B., Liu, X., Tiilikainen, P., Wang, M., Raustia, A., Pirttiniemi, P. (2011). Effect of estrogen and altered diet hardness on the expression of estrogen receptor alpha and matrix metalloproteinase-8 in rat condylar cartilage. Journal of Orofacial Pain, 25(3), 261-268.

Orajarvi, M., Puijola, E., Yu, S. B., Liu, X., Tiilikainen, P., Wang, M., Raustia, A., Pirttiniemi, P. (2012). Effect of estrogen and dietary loading on condylar cartilage. Journal of Orofacial Pain, 26(4), 328-336.

Price, W. A. (1936). Eskimo and Indian Field Studies in Alaska and Canada**Read before the Section on Histology, Physiology, Pathology, Bacteriology and Chemistry (Research) at the Seventy-Sixth Annual Session of the American Dental Association, St. Paul, Minn, August, 1934. The Journal of the American Dental Association (1922), 23(3), 417-437. doi:10.14219/jada.archive.1936.0057

Shimizu, Y., Ishida, T., Hosomichi, J., Kaneko, S., Hatano, K., \& Ono, T. (2013). Soft diet causes greater alveolar osteopenia in the mandible than in the maxilla. Archives of Oral Biology, 58(8), 907-911. doi:10.1016/j.archoralbio.2013.02.003

Shiono, K., Ito, G., Inuzuka, K., \& Hanihara, K. (1982). Dentofacial Morphology of Japanese Skeletal Remains from Later Jomon Period. Journal of the Anthropological Society of Nippon, 90(3), 259-268. doi:10.1537/ase1911.90.259

Stahl, S. S., \& Dreizen, S. (1964). The Adaptation of the Rat Periodontium to Prolonged Feeding of Pellet, Powder and Liquid Diets. Journal of Periodontology, 35(4), 312319. doi:10.1902/jop.1964.35.4.312

Tanaka, E., Sano, R., Kawai, N., Langenbach, G. E., Brugman, P., Tanne, K., \& van Eijden, T. M. (2007). Effect of food consistency on the degree of mineralization in the rat mandible. Annals of Biomedical Engineering, 35(9), 1617-1621. doi:10.1007/s10439007-9330-x

Tiilikainen, P., Raustia, A., \& Pirttiniemi, P. (2011). Effect of diet hardness on mandibular condylar cartilage metabolism. Journal of Orofacial Pain, 25(1), 68-74.

Tsichlaki, A., O'Brien, K., Johal, A., Marshman, Z., Benson, P., Colonio Salazar, F. B., \& Fleming, P. S. (2017). Development of a core outcome set for orthodontic trials using a mixed-methods approach: protocol for a multicentre study. Trials, 18(1), 366. doi:10.1186/s13063-017-2098-x

Vaid, L. K., Pradhan, P., \& Chakrabarti, S. (2002). Effect Of Dietary Consistency On The Growth Of The Condylar Cartilage Of The Mandible In Rats. Journal of the Anatomical Society of India, 51(2), 229-231.

Watt, D. G., \& Williams, C. H. M. (1951). The effects of the physical consistency of food on the growth and development of the mandible and the maxilla of the rat. American Journal of Orthodontics, 37(12), 895-928. doi:https://doi.org/10.1016/00029416(51)90101-7

Waugh, L. M. (1937). Influence of Diet on the Jaws and Face of the American Eskimo. The Journal of the American Dental Association and The Dental Cosmos, 24(10), 16401647. doi:10.14219/jada.archive.1937.0295

Wolff, J. (2010). Das Gesetz der Transformation der Knochen: Pro Business. 
Wood, B. F. (1971). Malocclusion in the modern Alaskan Eskimo. American Journal of Orthodontics, 60(4), 344-354.

Yamada, K., \& Kimmel, D. B. (1991). The effect of dietary consistency on bone mass and turnover in the growing rat mandible. Archives of Oral Biology, 36(2), 129-138. 


\section{Figure Captions}

Figure 1. PRISMA flow diagram for the identification and selection of eligible studies.

Figure 2. Frequency distribution (\%) of the scores assessed for each item of the ARRIVE guidelines in all studies included. Items were scored 0 (clearly inadequate), 1 (possibly inadequate) or 2 (clearly adequate)

Figure 3. Risk of bias graph: review authors' judgements about each risk of bias item presented as percentages across all included studies. The colors indicate low risk of bias (green), high risk of bias (red) or unclear risk of bias (yellow).

Figure 4. Risk of bias summary: review authors' judgements about each risk of bias item for each included study. The colors indicate low risk of bias (green), high risk of bias (red) or unclear risk of bias (yellow).

Figure 5. Random effects meta-analysis for the effect of soft versus hard diet on the anteroposterior condylar length in rats.

Figure 6. Random effects meta-analysis for the effect of soft versus hard diet on condylar width in rats.

Figure 7. Random effects meta-analysis for the effect of soft versus hard diet on the condylar length in mice. 
Tables

Table 1. Checklist of the 20 items corresponding to the ARRIVE guidelines

\begin{tabular}{|ll|}
\hline & Items \\
\hline 1 & Title \\
\hline 2 & Abstract \\
\hline 3 & Background \\
\hline 4 & Objectives \\
\hline 5 & Ethical statement \\
\hline 6 & Study design \\
\hline 7 & Experimental procedures \\
\hline 8 & Experimental animals \\
\hline 9 & Housing and husbandry \\
\hline 10 & Sample size \\
\hline 11 & Allocating animals to experimental \\
& groups \\
\hline 12 & Experimental outcomes \\
\hline 13 & Statistical methods \\
\hline 14 & Baseline data \\
\hline 15 & Numbers analyzed \\
\hline 16 & Outcomes and estimation \\
\hline 17 & Adverse events \\
\hline 18 & Interpretation/scientific implications \\
\hline 19 & Generalizability/translation \\
\hline 20 & Funding \\
\hline
\end{tabular}


Table 2. Characteristics of included studies (rats)

\begin{tabular}{|c|c|c|c|c|}
\hline Author & $\begin{array}{l}\text { Population/age/number } \\
\text { per group }\end{array}$ & Investigation method & Comparison & Outcome/observation time \\
\hline $\begin{array}{l}\text { (Orajarvi, } \\
2015 \text { ) }\end{array}$ & $\begin{array}{l}29 \text { female rats (unclear } \\
\text { strain) at the age of } 60 \\
\text { days divided in a } 7 \text { days } \\
\text { experimental group ( } 8 \\
\text { HD vs } 6 \text { SD) and a } 27 \\
\text { days experimental group } \\
\text { ( } 8 \text { HD vs } 7 \text { SD) }\end{array}$ & $\begin{array}{l}\text { Measurement of the total condylar cartilage } \\
\text { thickness in the most central sagittal section } \\
\text { (divided in ant., most sup. \& post. segments) } \\
\text { of histological sections }\end{array}$ & $\begin{array}{l}\text { Hard versus } \\
\text { soft diet } \\
\text { animals }\end{array}$ & $\begin{array}{l}\text { CA: No total cartilage thickness difference after } 7 \text { days in all } 3 \\
\text { segments but reduced thickness in SD animals after } 27 \text { days } \\
\text { in all } 3 \text { segments }\end{array}$ \\
\hline $\begin{array}{l}\text { lkeda et al. } \\
(2014)\end{array}$ & $\begin{array}{l}20 \text { male Wistar rats at } \\
\text { the age of } 3 \text { weeks ( } 10 \\
\text { HD vs } 10 \text { SD) }\end{array}$ & $\begin{array}{l}\text { Micro- CT analysis of mid- sagittal condylar } \\
\text { specimens divided in ant., most sup. \& post. } \\
\text { regions. Measurement of the total condylar } \\
\text { cartilage thickness in mid-sagittal direction } \\
\text { (divided in ant., sup. \& post. region) on } \\
\text { histological sections }\end{array}$ & $\begin{array}{l}\text { Hard versus } \\
\text { soft diet } \\
\text { animals }\end{array}$ & $\begin{array}{l}\text { TMJ/Co: After } 47 \text { days the ratio bone volume/trabecular } \\
\text { volume was lower in all } 3 \text { regions of SD animals, trabecular } \\
\text { thickness was lower in sup. \& post. region of SD animals while } \\
\text { there was no difference between HD \& SD animals in } \\
\text { trabecular number, trabecular separation and trabecular } \\
\text { spacing } \\
\text { CA: Thicker total cartilage thickness and hypertrophic zone } \\
\text { thickness in HD animals after } 47 \text { days in all } 3 \text { regions }\end{array}$ \\
\hline $\begin{array}{l}\text { (Hichijo et al., } \\
\text { 2014) }\end{array}$ & $\begin{array}{l}14 \text { male Wistar rats at } \\
\text { the age of } 3 \text { weeks ( } 7 \\
\text { HD vs } 7 \text { SD) }\end{array}$ & $\begin{array}{l}\text { Measurement of the total condylar cartilage } \\
\text { thickness in the intermediate region of mid- } \\
\text { sagittal histological sections }\end{array}$ & $\begin{array}{l}\text { Hard versus } \\
\text { soft diet } \\
\text { animals }\end{array}$ & $\begin{array}{l}\text { CA: Thicker total cartilage thickness after } 2 \text { weeks in HD } \\
\text { animals }\end{array}$ \\
\hline $\begin{array}{l}\text { (Guerreiro et } \\
\text { al., 2013) }\end{array}$ & $\begin{array}{l}24 \text { male Wistar rats } \\
\text { (albinus norvegicus) at } \\
\text { the age of } 3 \text { weeks ( } 12 \\
\text { HD vs } 12 \text { SD) }\end{array}$ & $\begin{array}{l}\text { Condyle length measurement on lateral } \\
\text { photographs of dry mandibles (tangent line } \\
\text { to the notches and then measured } \\
\text { perpendicular to that line up to the highest } \\
\text { portion of the condylar curve) }\end{array}$ & $\begin{array}{l}\text { Hard versus } \\
\text { soft diet } \\
\text { animals }\end{array}$ & $\begin{array}{l}\text { TMJ/Co: No difference in condylar length after } 50 \text { days } \\
\text { between SD and HD animals }\end{array}$ \\
\hline $\begin{array}{l}\text { (Shimizu et } \\
\text { al., 2013) }\end{array}$ & $\begin{array}{l}12 \text { male Wistar rats at } \\
\text { the age of } 3 \text { weeks }(6 \\
\text { HD vs } 6 \text { SD) }\end{array}$ & $\begin{array}{l}\text { Micro- CT analysis of the inter- radicular } \\
\text { alveolar bone in the first molar region }\end{array}$ & $\begin{array}{l}\text { Hard versus } \\
\text { soft diet } \\
\text { animals }\end{array}$ & $\begin{array}{l}\text { ABM: Ratio bone volume/trabecular volume, trabecular } \\
\text { thickness, trabecular number, trabecular spacing width \& } \\
\text { trabecular star volume was increased in HD animals after } 9 \\
\text { weeks, whereas marrow space star volume was increased in } \\
\text { SD animals }\end{array}$ \\
\hline $\begin{array}{l}\text { (Orajarvi et } \\
\text { al., 2012) }\end{array}$ & $\begin{array}{l}16 \text { female rats (unclear } \\
\text { strain) at the age of } 3 \\
\text { weeks ( } 8 \text { HD vs } 8 \text { SD) }\end{array}$ & $\begin{array}{l}\text { Measurement of total condylar cartilage } \\
\text { thickness in the most central sagittal section } \\
\text { (divided in ant., most sup. \& post. segments } \\
\text { of equal lengths) of histological sections }\end{array}$ & $\begin{array}{l}\text { Hard versus } \\
\text { soft diet } \\
\text { animals }\end{array}$ & $\begin{array}{l}\text { CA: No difference in total cartilage thickness after } 46 \text { days in } \\
\text { all } 3 \text { segments between HD and SD animals }\end{array}$ \\
\hline $\begin{array}{l}\text { (Orajarvi et } \\
\text { al., 2011) }\end{array}$ & $\begin{array}{l}16 \text { female rats (unclear } \\
\text { strain) at the age of } 3 \\
\text { weeks ( } 8 \text { HD vs } 8 \text { SD) }\end{array}$ & $\begin{array}{l}\text { Measurement of proliferative cartilage layer } \\
\text { thickness in the superior part of the most } \\
\text { central sagittal section on histological } \\
\text { sections }\end{array}$ & $\begin{array}{l}\text { Hard versus } \\
\text { soft diet } \\
\text { animals }\end{array}$ & CA: Thicker proliferative layer in HD animals after 46 days \\
\hline $\begin{array}{l}\text { (Tiilikainen et } \\
\text { al., 2011) }\end{array}$ & $\begin{array}{l}32 \text { female Sprague } \\
\text { Dawley rats at the age of } \\
3 \text { weeks ( } 2 \times 8 \text { HD vs } 2 \times 8 \\
\text { SD) }\end{array}$ & $\begin{array}{l}\text { Measurement of the total cartilage thickness } \\
\text { in the most superior part of the most central } \\
\text { sagittal section on histological sections }\end{array}$ & $\begin{array}{l}\text { Hard versus } \\
\text { soft diet } \\
\text { animals }\end{array}$ & $\begin{array}{l}\text { CA: Thicker total cartilage thickness after } 33 \text { days hard diet } \\
\text { feeding compared to } 30 \text { days soft diet feeding. Same findings } \\
\text { after } 53 \text { days hard diet feeding compared to } 50 \text { days soft diet } \\
\text { feeding. }\end{array}$ \\
\hline
\end{tabular}




\begin{tabular}{|c|c|c|c|c|}
\hline $\begin{array}{l}\text { (Mavropoulos } \\
\text { et al., 2010) }\end{array}$ & $\begin{array}{l}38 \text { male Sprague } \\
\text { Dawley rats at the age of } \\
3 \text { weeks ( } 16 \text { HD vs } 22 \\
\text { SD) }\end{array}$ & $\begin{array}{l}\text { Micro- CT analysis of the alveolar bone } \\
\text { between and apical the first molar roots } \\
\text { Height of the molar alveolar bone measured } \\
\text { from the mandibular canal to the bifurcation } \\
\text { of the first molar on micro- CT's } \\
\text { Width of the molar alveolar bone at the } \\
\text { midlevel of the } 1^{\text {st }} \text { molar apices on micro- } \\
\text { CT's }\end{array}$ & $\begin{array}{l}\text { Hard versus } \\
\text { soft diet } \\
\text { animals }\end{array}$ & $\begin{array}{l}\text { ABM: Ratio bone volume/trabecular volume, trabecular } \\
\text { thickness, trabecular number and connectivity density was } \\
\text { increased in HD animals, whereas trabecular separation and } \\
\text { bone surface/bone volume was increased in SD animals after } \\
27 \text { weeks experimental period. } \\
\text { Molar alveolar bone height was found to be increased in SD } \\
\text { animals, while alveolar bone width was increased in HD } \\
\text { animals after } 27 \text { weeks. }\end{array}$ \\
\hline $\begin{array}{l}\text { (Kingsmill et } \\
\text { al., 2010) }\end{array}$ & $\begin{array}{l}14 \text { female rats (unclear } \\
\text { strain) at the age of } 2 \\
\text { months ( } 7 \text { HD vs } 7 \text { SD) }\end{array}$ & $\begin{array}{l}\text { Micro- CT analysis to determine the amount } \\
\text { of bone volume in the furcation from the } 1^{\text {st }} \\
\text { to the } 3^{\text {rd }} \text { molar. } \\
\text { qSE-SEM to determine the mineral density } \\
\text { on the buccal and lingual alveolar side. }\end{array}$ & $\begin{array}{l}\text { Hard versus } \\
\text { soft diet } \\
\text { animals }\end{array}$ & $\begin{array}{l}\text { ABM: Smaller amount of bone volume in SD animals after } 20 \\
\text { experimental weeks (this difference disappeared after } \\
\text { correction for weight). } \\
\text { Soft diet lead to an increase in mineralization density on the } \\
\text { lingual alveolar side while there was no difference on the } \\
\text { buccal alveolar side after } 20 \text { weeks. }\end{array}$ \\
\hline $\begin{array}{l}\text { (Odman et } \\
\text { al., 2008) }\end{array}$ & $\begin{array}{l}38 \text { male Sprague } \\
\text { Dawley rats at the age of } \\
3 \text { weeks ( } 16 \mathrm{HD} \text { vs } 22 \\
\text { SD) }\end{array}$ & $\begin{array}{l}\text { Lateral photographs of transilluminated dry } \\
\text { hemimandibles to measure molar alveolar } \\
\text { anterior (first molar) and posterior height } \\
\text { (third molar) as a perpendicular distance } \\
\text { from the deepest point of the alveolar crest } \\
\text { to a reference line through mandibular and } \\
\text { mental foramina as well as } \\
\text { condylar process area delimited by a tangent } \\
\text { to both upper and lower mandibular notches. } \\
\text { In evaluating condyle process length, a line } \\
\text { was drawn tangent to the notches and then } \\
\text { length was measured perpendicular to that } \\
\text { lint to the highest portion of the condylar } \\
\text { curve. }\end{array}$ & $\begin{array}{l}\text { Hard versus } \\
\text { soft diet } \\
\text { animals }\end{array}$ & $\begin{array}{l}\text { TMJ/Co: No difference between HD and SD condylar process } \\
\text { area and condylar length after } 27 \text { weeks. }\end{array}$ \\
\hline $\begin{array}{l}\text { (Abed et al., } \\
2007)\end{array}$ & $\begin{array}{l}32 \text { male Sprague } \\
\text { Dawley rats at the age of } \\
23 \text { days ( } 16 \text { HD vs } 16 \\
\text { SD) }\end{array}$ & $\begin{array}{l}\text { Mandibular alveolar bone height was } \\
\text { measured on lateral cephalograms as a } \\
\text { distance from the junction of the alveolar } \\
\text { bone and the mesial surface of the first } \\
\text { mandibular molar perpendicular to a line } \\
\text { through Gn (the most inferior point on the } \\
\text { ramus) and I1 (the most anterior and superior } \\
\text { point on the alveolar bone of the mandibular } \\
\text { incisors) }\end{array}$ & $\begin{array}{l}\text { Hard versus } \\
\text { soft diet } \\
\text { animals }\end{array}$ & $\begin{array}{l}\text { ABM: Increased mandibular alveolar bone height in HD } \\
\text { animals after } 8 \text { experimental weeks. }\end{array}$ \\
\hline $\begin{array}{l}\text { (Tanaka et } \\
\text { al., 2007) }\end{array}$ & $\begin{array}{l}15 \text { male Wistar rats at } \\
\text { the age of } 3 \text { weeks ( } 6 \\
\text { HD vs } 9 \text { SD) }\end{array}$ & $\begin{array}{l}\text { Micro- CT analysis to determine the degree } \\
\text { of mineralization in the center of the condyle } \\
\text { and in the buccal cortical bone of the } \\
\text { mandibular body }\end{array}$ & $\begin{array}{l}\text { Hard versus } \\
\text { soft diet } \\
\text { animals }\end{array}$ & $\begin{array}{l}\text { TMJ/Co: Degree of condylar trabecular bone mineralization } \\
\text { higher in HD animals after } 9 \text { weeks. } \\
\text { ABM: Degree of mineralization in the buccal bone was higher } \\
\text { in SD animals after } 9 \text { weeks. }\end{array}$ \\
\hline $\begin{array}{l}\text { (Vaid et al., } \\
\text { 2002) }\end{array}$ & $\begin{array}{l}30 \text { ( } 15 \text { males and } 15 \\
\text { females) "albino" rats at } \\
\text { the age of } 2 \text { weeks ( } 15\end{array}$ & $\begin{array}{l}\text { Maximum antero- posterior length and width } \\
\text { measurement on dry condyle } \\
\text { Maximum depth of the condylar cartilage on } \\
\text { its lateral surface on dry condyle }\end{array}$ & $\begin{array}{l}\text { Hard versus } \\
\text { soft diet } \\
\text { animals }\end{array}$ & $\begin{array}{l}\text { TMJ/Co: Increased condyle length and width in HD animals } \\
\text { after } 8 \text { weeks } \\
\text { CA: Increased depth in HD animals after } 8 \text { weeks }\end{array}$ \\
\hline
\end{tabular}




\begin{tabular}{|c|c|c|c|c|}
\hline & $\begin{array}{l}\text { HD vs } 15 \text { SD, gender } \\
\text { distribution unclear) }\end{array}$ & & & \\
\hline $\begin{array}{l}\text { (Maki et al., } \\
\text { 2002) }\end{array}$ & $\begin{array}{l}20 \text { male Wistar rats at } \\
\text { the age of } 3 \text { weeks ( } 10 \\
\text { HD vs } 10 \text { SD) }\end{array}$ & $\begin{array}{l}\text { Micro- densiometry of the condyloid process } \\
\text { area in reference to aluminium (mean bone } \\
\text { mineral density of the whole region up to a } \\
\text { line drawn tangent to the notches) }\end{array}$ & $\begin{array}{l}\text { Hard versus } \\
\text { soft diet } \\
\text { animals }\end{array}$ & $\begin{array}{l}\text { TMJ/Co: No difference in density between HD and SD } \\
\text { animals after } 6 \text { weeks }\end{array}$ \\
\hline $\begin{array}{l}\text { (Kiliaridis et } \\
\text { al., 1999) }\end{array}$ & $\begin{array}{l}20 \text { male Sprague } \\
\text { Dawley rats at the age of } \\
4 \text { weeks ( } 10 \mathrm{HD} \text { vs } 10 \\
\text { SD) }\end{array}$ & $\begin{array}{l}\text { Anteroposterior length and width of the } \\
\text { condyle was measured on axial photographs } \\
\text { of dry mandibles } \\
\text { Measurement of the hypertrophic zone } \\
\text { cartilage thickness on projected most central } \\
\text { sagittal sections in the anterior, intermediate } \\
\text { and posterior part }\end{array}$ & $\begin{array}{l}\text { Hard versus } \\
\text { soft diet } \\
\text { animals }\end{array}$ & $\begin{array}{l}\text { TMJ/Co: Increased condylar length and width in HD animals } \\
\text { after } 4 \text { experimental weeks } \\
\text { CA: Decreased thickness in the anterior part of SD animals, } \\
\text { no difference in the intermediate part and increased thickness } \\
\text { in the posterior part of SD animals after } 4 \text { weeks }\end{array}$ \\
\hline $\begin{array}{l}\text { (Bresin et al., } \\
\text { 1999) }\end{array}$ & $\begin{array}{l}28 \text { male Sprague } \\
\text { Dawley rats with an } \\
\text { initial age of } 90 \mathrm{~g}(14 \mathrm{HD} \\
\text { vs } 14 \mathrm{SD}) . \text { (This weight } \\
\text { corresponds to } 28 \text { days } \\
\text { of age after e- mail } \\
\text { contacting with author) }\end{array}$ & $\begin{array}{l}\text { Contact microradiographs of coronal } \\
\text { condylar sections in antero- posterior } \\
\text { direction in reference to aluminium as well } \\
\text { as coronal sections perpendicular to the } \\
\text { mandibular plane in the region between the } \\
\text { medial and distal roots of the first molar }\end{array}$ & $\begin{array}{l}\text { Hard versus } \\
\text { soft diet } \\
\text { animals }\end{array}$ & $\begin{array}{l}\text { TMJ/Co: Bone mass } 0,5-1 \mathrm{~mm} \text { from the posterior edge of the } \\
\text { condyle was increased in HD animals, while bone density in } \\
\text { the lateral and medial cortical bone showed both no difference } \\
\text { after } 4 \text { experimental weeks. } \\
\text { ABM: Increased apical bone mass in HD animals, increased } \\
\text { medial bone density in HD animals but no difference in the } \\
\text { lateral cortical bone apical the first molar. Increased lateral } \\
\text { thickness of the mandibular cortical bone in HD animals but no } \\
\text { difference in the medial cortical bone after } 4 \text { weeks. }\end{array}$ \\
\hline $\begin{array}{l}\text { (Endo et al., } \\
\text { 1998) }\end{array}$ & $\begin{array}{l}18 \text { male Wistar rats with } \\
\text { an initial age of } 3 \text { weeks } \\
\text { were divided in } 3 \text { groups } \\
\text { à } 6 \text { animals ( } 3 \times 3 \text { HD vs } \\
3 \times 3 \text { SD, group size not } \\
\text { specified, no answer } \\
\text { after contacting author) }\end{array}$ & $\begin{array}{l}\text { Direct measurement of anteroposterior } \\
\text { length and width on dry condyles } \\
\text { Measurement of cartilage thickness at the } \\
\text { center of the condyle in frontal direction }\end{array}$ & $\begin{array}{l}\text { Hard versus } \\
\text { soft diet } \\
\text { animals }\end{array}$ & $\begin{array}{l}\text { TMJ/Co: No difference in anteroposterior length was found } \\
\text { between HD and SD animals after } 10,13 \& 17 \text { experimental } \\
\text { weeks whereas width was increased in HD animal's at all } \\
\text { three time points. } \\
\text { CA: Thicker total cartilage thickness after } 10,13 \text { and } 17 \\
\text { experimental weeks in SD animals. Increased articular zone } \\
\text { thickness, proliferative cell layer thickness, chondroblastic } \\
\text { layer thickness and hypertrophic zone thickness in HD } \\
\text { animals after } 10,13 \text { and } 17 \text { experimental weeks. }\end{array}$ \\
\hline $\begin{array}{l}\text { (Kiliaridis et } \\
\text { al., 1996) }\end{array}$ & $\begin{array}{l}28 \text { male Sprague } \\
\text { Dawley rats with an } \\
\text { initial age of } 4 \text { weeks ( } 14 \\
\text { HD vs } 14 \text { SD) }\end{array}$ & $\begin{array}{l}\text { Standard } x \text { - ray of the mandibular half in } \\
\text { reference to aluminium to determine bone } \\
\text { mass }\end{array}$ & $\begin{array}{l}\text { Hard versus } \\
\text { soft diet } \\
\text { animals }\end{array}$ & $\begin{array}{l}\text { TMJ/Co: Bone mass in an area on the lateral half of the } \\
\text { mandible situated } 0.22 \mathrm{~mm} \text { anterior to the posterior border of } \\
\text { the condyle was increased in HD animals after } 4 \text { experimental } \\
\text { weeks. } \\
\text { ABM: Bone mass in an area between and apical to the middle } \\
\text { and distal roots of the first molar was increased in HD animals } \\
\text { after } 4 \text { weeks. }\end{array}$ \\
\hline $\begin{array}{l}\text { (Bresin et al., } \\
\text { 1994) }\end{array}$ & $\begin{array}{l}28 \text { male "albino" rats } \\
\text { with an initial age of } 29 \\
\text { days ( } 14 \text { HD vs } 14 \text { SD) }\end{array}$ & $\begin{array}{l}\text { Contact microradiograms of mandibular } \\
\text { alveolar bone in coronal direction were cut } \\
\text { perpendicular to the mandibular plane } \\
\text { (starting from the } 1^{\text {st }} \text { molar and reaching to } \\
\text { the } 3^{\text {rd }} \text { molar). }\end{array}$ & $\begin{array}{l}\text { Hard versus } \\
\text { soft diet } \\
\text { animals }\end{array}$ & $\begin{array}{l}\text { PL: Buccal periodontal space width was increased in HD } \\
\text { animals but there was no difference in lingual periodontal } \\
\text { space width after } 4 \text { experimental weeks. } \\
\text { ABM: Measurement from the most buccal point to the most } \\
\text { lingual point showed increased width in HD animals after } 4 \\
\text { weeks }\end{array}$ \\
\hline
\end{tabular}




\begin{tabular}{|c|c|c|c|c|}
\hline $\begin{array}{l}\text { (Yamada \& } \\
\text { Kimmel, } \\
\text { 1991) }\end{array}$ & $\begin{array}{l}24 \text { female rats (unclear } \\
\text { strain) with an initial age } \\
\text { of } 3 \text { weeks were divided } \\
\text { in } 2 \text { groups à } 12 \text { animals } \\
\text { ( } 2 \times 6 \text { HD vs } 2 \times 6 \text { SD) }\end{array}$ & $\begin{array}{l}\text { Parasagittal histological sections of the } \\
\text { condyle to determine trabecular bone } \\
\text { volume of the primary and secondary } \\
\text { spongiosa as well as superior condylar } \\
\text { cartilage thickness }\end{array}$ & $\begin{array}{l}\text { Hard versus } \\
\text { soft diet } \\
\text { animals }\end{array}$ & $\begin{array}{l}\text { TMJ/Co: The trabecular bone volume of the primary and } \\
\text { secondary spongiosa was increased in HD animals after } 4 \\
\text { weeks but there was no difference after } 8 \text { weeks. } \\
\text { CA: The proliferative cell layer thickness of the superior } \\
\text { condylar cartilage showed no difference after } 4 \text { weeks but was } \\
\text { thicker in the HD animals after } 8 \text { weeks, whereas the } \\
\text { thickness of the chondroblastic layer showed no difference at } \\
\text { both time points. The hypertrophic zone was thicker after } 4 \\
\text { weeks in HD animals and showed no difference after } 8 \text { weeks. }\end{array}$ \\
\hline $\begin{array}{l}\text { (Bouvier, } \\
\text { 1988) }\end{array}$ & $\begin{array}{l}54 \text { Sprague Dawley rats } \\
\text { with an initial age of } 3 \\
\text { weeks (9f \& } 7 \mathrm{~m} \mathrm{HD} \text { vs } 9 f \\
\& 7 \mathrm{~m} \mathrm{SD}=\text { growing rats) } \\
\text { and approximately } 4 \\
\text { months (12m HD \& } 10 \mathrm{~m} \\
\mathrm{SD}=\text { mature rats) }\end{array}$ & $\begin{array}{l}\text { Histological central portion sections of the } \\
\text { condyle in coronal direction to evaluate } \\
\text { subcondylar trabecular bone area } \\
\text { Direct length and width measurement on the } \\
\text { dry condyle } \\
\text { Measurement of cartilage thickness at the } \\
\text { central portion of the condyle in coronal } \\
\text { direction }\end{array}$ & $\begin{array}{l}\text { Hard versus } \\
\text { soft diet } \\
\text { animals }\end{array}$ & $\begin{array}{l}\text { TMJ/Co: Subcondylar trabecular bone area of growing (after } 4 \\
\text { weeks) and mature rats (after } 12 \text { weeks) increased in HD } \\
\text { animals. } \\
\text { Anteroposterior length and width (separated according to sex) } \\
\text { of growing females, growing males and mature males were } \\
\text { increased in HD animals compared to SD animals. } \\
\text { CA: Total cartilage thickness, articular zone thickness, } \\
\text { proliferative zone thickness, chondroblastic zone thickness } \\
\text { and hypertrophic zone thickness of growing (after } 4 \text { weeks) } \\
\text { and mature rats (after } 12 \text { weeks) (sex for this measurement } \\
\text { not separated) was thicker in HD animals }\end{array}$ \\
\hline $\begin{array}{l}\text { (Bouvier \& } \\
\text { Zimny, 1987) }\end{array}$ & $\begin{array}{l}53 \text { Sprague Dawley rats } \\
\text { with an initial age of } 4 \\
\text { weeks ( } 9 f \& 6 \mathrm{~m} \mathrm{HD} \text { vs } 9 f \\
\& 3 \mathrm{~m} \mathrm{SD}=\text { growing rats) } \\
\text { and "mature" animals } \\
\text { ( } 14 \mathrm{~m} \text { HD \& } 12 \mathrm{~m} \mathrm{SD} \mathrm{=} \\
\text { mature rats) }\end{array}$ & $\begin{array}{l}\text { Direct length and width measurement on dry } \\
\text { condyle }\end{array}$ & $\begin{array}{l}\text { Hard versus } \\
\text { soft diet } \\
\text { animals }\end{array}$ & $\begin{array}{l}\text { TMJ/Co: Anteroposterior length and width (separated } \\
\text { according to sex) of growing females, growing males (both } \\
\text { after } 4 \text { weeks) and mature males (after } 12 \text { weeks) were } \\
\text { increased in HD animals. }\end{array}$ \\
\hline $\begin{array}{l}\text { (McFadden } \\
\text { et al., 1986) }\end{array}$ & $\begin{array}{l}19 \text { Fischer strain albino } \\
\text { rats with an initial age of } \\
3 \text { weeks ( } 5 f \& 4 \mathrm{~m} \text { HD vs } \\
5 f \& 5 \mathrm{~m} \mathrm{SD})\end{array}$ & $\begin{array}{l}\text { A line was drawn tangent to the notches (on } \\
\text { lateral photograph of dry mandible). Length } \\
\text { was measured perpendicular to that line up } \\
\text { to the highest portion of the condylar curve }\end{array}$ & $\begin{array}{l}\text { Hard versus } \\
\text { soft diet } \\
\text { animals }\end{array}$ & $\begin{array}{l}\text { TMJ/Co: HD animals showed increased length (but they found } \\
\text { a sexual dimorphism: smaller values in females) : After } 16 \\
\text { experimental weeks }\end{array}$ \\
\hline $\begin{array}{l}\text { (Hinton \& } \\
\text { Carlson, } \\
1986)\end{array}$ & $\begin{array}{l}15 \text { male Sprague } \\
\text { Dawley rats with an } \\
\text { initial age of } 3 \text { weeks ( } 7 \\
\text { HD vs } 8 \text { SD) }\end{array}$ & $\begin{array}{l}\text { Histological sections of the condyle in } \\
\text { sagittal direction }\end{array}$ & $\begin{array}{l}\text { Hard versus } \\
\text { soft diet } \\
\text { animals }\end{array}$ & $\begin{array}{l}\text { TMJ/Co: Visual evaluation showed a reduced density and size } \\
\text { of the trabeculation in SD animals after } 26 \text { days } \\
\text { CA: Total cartilage thickness, proliferative cell layer thickness } \\
\text { and chondroblastic layer thickness was reduced in SD animals } \\
\text { in the superior region after } 26 \text { days. No difference in the } \\
\text { posterior and posterosuperior region. }\end{array}$ \\
\hline $\begin{array}{l}\text { (Bouvier \& } \\
\text { Hylander, } \\
1984 \text { ) }\end{array}$ & $\begin{array}{l}20 \text { male Long Evans rats } \\
\text { with an initial age of } 23 \\
\text { days ( } 5 \mathrm{HD} \text { vs } 5 \mathrm{SD}= \\
\text { weanling rats) and } 6 \\
\text { weeks ( } 5 \mathrm{HD} \text { vs } 5 \mathrm{SD}= \\
\text { juvenile rats) }\end{array}$ & $\begin{array}{l}\text { Histological sections of the condyle in } \\
\text { sagittal direction (one SD condyle was } \\
\text { damaged, unclear if weanling or juvenile) } \\
\text { Direct length and width measurement on dry } \\
\text { condyle } \\
\text { Maximum depth of the condylar cartilage on } \\
\text { its lateral surface of dry condyle }\end{array}$ & $\begin{array}{l}\text { Hard versus } \\
\text { soft diet } \\
\text { animals }\end{array}$ & $\begin{array}{l}\text { TMJ/Co: Visual evaluation showed a reduced quantity of the } \\
\text { subchondral bone in both weanling (after } 5 \text { weeks) and } \\
\text { juvenile SD rats (after } 8 \text { weeks). } \\
\text { Both HD weanling and juvenile rats showed increased width } \\
\text { and length dimensions of the condyle. } \\
\text { CA: In the superior region of the condyle at its thickest portion } \\
\text { the total cartilage thickness, articular zone thickness and } \\
\text { proliferative cell layer thickness was increased in weanling HD } \\
\text { animals but showed no difference in juvenile animals. The }\end{array}$ \\
\hline
\end{tabular}




\begin{tabular}{|c|c|c|c|c|}
\hline & & & & $\begin{array}{l}\text { hypertrophic zone thickness showed no difference in both } \\
\text { weanling and juvenile animals. } \\
\text { Increased condylar depth in weanling and juvenile HD animals }\end{array}$ \\
\hline $\begin{array}{l}\text { (Beecher \& } \\
\text { Corruccini, } \\
\text { 1981a) }\end{array}$ & $\begin{array}{l}30 \text { male and } 30 \text { female } \\
\text { Sprague Dawley rats } \\
\text { (unclear distribution) with } \\
\text { an initial age of } 3 \text { weeks } \\
\text { (30 HD vs } 30 \text { SD) }\end{array}$ & $\begin{array}{l}\text { Direct anteroposterior length measurement } \\
\text { on dry condyle }\end{array}$ & $\begin{array}{l}\text { Hard versus } \\
\text { soft diet } \\
\text { animals }\end{array}$ & $\begin{array}{l}\text { TMJ/Co: No difference between HD and SD animals was } \\
\text { found after } 4 \text { months }\end{array}$ \\
\hline $\begin{array}{l}\text { (Stahl \& } \\
\text { Dreizen, } \\
1964)\end{array}$ & $\begin{array}{l}26 \text { male Sprague } \\
\text { Dawley rats with an } \\
\text { initial age of } 5 \text { weeks ( } 13 \\
\text { HD vs } 13 \text { SD) }\end{array}$ & $\begin{array}{l}\text { Central mesio-distally oriented sections of } \\
\text { the mandibular first and second molars. }\end{array}$ & $\begin{array}{l}\text { Hard versus } \\
\text { soft diet } \\
\text { animals }\end{array}$ & $\begin{array}{l}\text { PL: SD animals showed a narrower periodontal membrane } \\
\text { after } 68,49 \text { weeks in comparison to HD animals after } 70,86 \\
\text { weeks }\end{array}$ \\
\hline $\begin{array}{l}\text { (Barber et al., } \\
1963)\end{array}$ & $\begin{array}{l}30 \text { male Long Evans rats } \\
\text { with an initial age of } 3 \\
\text { weeks ( } 15 \mathrm{HD} \text { vs } 15 \mathrm{SD})\end{array}$ & $\begin{array}{l}\text { On a projected silhouette of the condyle a } \\
\text { line was drawn tangent to the deepest } \\
\text { depression on each side of the condyle. } \\
\text { Length was measured perpendicular to that } \\
\text { line to the highest portion of the condylar } \\
\text { curve. } \\
\text { Area between the point of deepest } \\
\text { depression between the condyloid process } \\
\text { and the point of deepest depression } \\
\text { between the condyloid process and the } \\
\text { angular process was measured on a } \\
\text { projected silhouette of the condylar process }\end{array}$ & $\begin{array}{l}\text { Hard versus } \\
\text { soft diet } \\
\text { animals }\end{array}$ & $\begin{array}{l}\text { TMJ/Co: No difference in condylar length between HD and SD } \\
\text { animals after } 18 \text { experimental weeks } \\
\text { Increased condylar process area in HD animals compared to } \\
\text { SD animals after } 18 \text { weeks }\end{array}$ \\
\hline $\begin{array}{l}\text { (Watt \& } \\
\text { Williams, } \\
1951)\end{array}$ & $\begin{array}{l}60 \text { rats (unclear strain) } \\
\text { with an initial age of } \\
\text { "approx." } 3 \text { weeks }(16 \mathrm{~m} \\
\& 14 \mathrm{f} \mathrm{HD} \text { vs } 16 \mathrm{~m} \& 14 \mathrm{f} \\
\text { SD) }\end{array}$ & $\begin{array}{l}\text { Standard radiograph of hemimandible using } \\
\text { a constant technique. } \\
\text { Measurement of molar alveolar bone width } \\
\text { on dry mandibles in the region of the distal } \\
\text { root of the } 1^{\text {st }} \text { molar. }\end{array}$ & $\begin{array}{l}\text { Hard versus } \\
\text { soft diet } \\
\text { animals }\end{array}$ & $\begin{array}{l}\text { TMJ/Co: Visual evaluation showed denser articulating } \\
\text { condylar surfaces in HD animals after } 4 \text { months } \\
\text { ABM: Thicker molar alveolar bone width in HD animals after } 4 \\
\text { months }\end{array}$ \\
\hline
\end{tabular}

$\mathrm{f}$, female; $\mathrm{m}$, male; HD, hard diet; SD, soft diet; TMJ/Co, temporomandibular joint/condyle; ABM, mandibular alveolar bone; CA, condylar cartilage; PL, periodontal ligament. 
Table 3. Characteristics of included studies (mice).

\begin{tabular}{|c|c|c|c|c|}
\hline Author & $\begin{array}{l}\text { Population/age/number } \\
\text { per group }\end{array}$ & Investigation method & Comparison & Outcome/observation time \\
\hline $\begin{array}{l}\text { (Enomoto } \\
\text { et al., } \\
2014)\end{array}$ & $\begin{array}{l}20 \text { male CD-1 mice at } \\
\text { the age of } 3 \text { weeks } \\
\text { divided in a } 1 \text { week } \\
\text { experimental group ( } 5 \\
\text { HD vs } 5 \text { SD) and a } 4 \\
\text { week experimental } \\
\text { group ( } 5 \text { HD vs } 5 \text { SD) }\end{array}$ & $\begin{array}{l}\text { Measurement of the total condylar } \\
\text { cartilage thickness, the APC- zone } \\
\text { (articular, proliferative and } \\
\text { chondroblastic zone) and the } \\
\text { hypertrophic zone in the most } \\
\text { central coronal section of } \\
\text { histological sections }\end{array}$ & $\begin{array}{l}\text { Hard versus } \\
\text { soft diet } \\
\text { animals }\end{array}$ & $\begin{array}{l}\text { CA: No total cartilage and APC- zone thickness differences after } 1 \\
\text { respectively } 4 \text { weeks in the superior region. In contrast thickness of } \\
\text { the hypertrophic zone was increased after both } 1 \text { and } 4 \text { weeks in HD } \\
\text { animals. }\end{array}$ \\
\hline $\begin{array}{l}\text { (Enomoto } \\
\text { et al., } \\
2010)\end{array}$ & $\begin{array}{l}20 \text { male imprinting } \\
\text { control region mice at } \\
\text { the age of } 3 \text { weeks ( } 10 \\
\mathrm{HD} \text { vs } 10 \mathrm{SD})\end{array}$ & $\begin{array}{l}\text { Condylar width (left-to-right } \\
\text { thickness of the condyle) and } \\
\text { condylar length (in the lateral view) } \\
\text { was measured on micro- CT's }\end{array}$ & $\begin{array}{l}\text { Hard versus } \\
\text { soft diet } \\
\text { animals }\end{array}$ & $\begin{array}{l}\text { TMJ/Co: Condyle width increased after } 1 \text { experimental week in HD } \\
\text { animals but no difference after } 4 \text { experimental weeks. No difference in } \\
\text { condylar length after both } 1 \text { and } 4 \text { experimental weeks }\end{array}$ \\
\hline $\begin{array}{l}\text { (Ito et al., } \\
1988)\end{array}$ & $\begin{array}{l}100 \mathrm{HD} \text { and } 100 \mathrm{SD} \\
\text { male } \mathrm{C} 3 \mathrm{H} / \mathrm{He} \text { mice at } \\
\text { the age of } 2 \text { weeks } \\
\text { were divided in } 1,3,5, \\
10 \text { and } 18 \text { weeks } \\
\text { experimental subgroups }\end{array}$ & $\begin{array}{l}\text { Measurement of the condyle } \\
\text { process length with soft } x \text { - ray } \\
\text { arrangement (lateral view) }\end{array}$ & $\begin{array}{l}\text { Hard versus } \\
\text { soft diet } \\
\text { animals }\end{array}$ & $\begin{array}{l}\text { TMJ/Co: Increased condyle length in HD animals after 1, 3, 5, } 10 \text { and } \\
18 \text { experimental weeks }\end{array}$ \\
\hline
\end{tabular}

$\mathrm{HD}$, hard diet; SD, soft diet; TMJ/Co, temporomandibular joint/condyle; CA, condylar cartilage. 


\section{Appendix 1}

MEDLINE search

Limits: no language restriction applied

Publication date: no restriction

Search Builder: 'All Fields'

Four consecutive searches combined with "AND" Boolean operator, using "OR" between free text terms or keywords:

1. mice

2. mouse

3. rat

4. rat $^{*}$

5. rodent

6. 1 OR 2 OR 3 OR 4 OR 5

7. alveolar bone

8. mandible

9. mandib*

10. alveol*

11. condyle

12. condyl*

13. condylar bone

14. periodontal ligament

15. periodontal ligament space

16. bone density

17. cartilage

18. mandibular cartilage

19. condylar cartilage

20. temporomandibular joint

21. 7 OR 8 OR 9 OR 10 OR 11 OR 12 OR 13 OR 14 OR 15 OR 16 OR 17 OR 18 OR 19 OR 20 
22. hard diet

23. soft diet

24. Masticatory function

25. 22 OR 23 OR 24

26. 6 AND 21 AND 25 


\section{Figure 1}

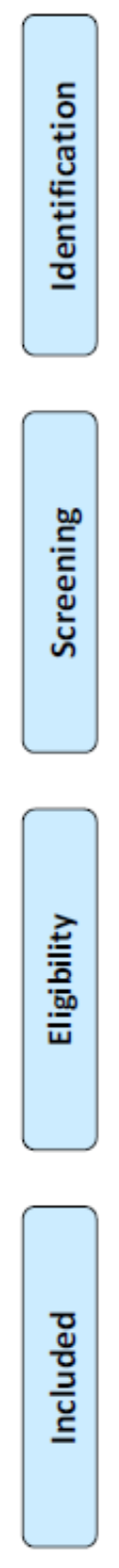

Records identified through database and registry searching ( $n=995)$

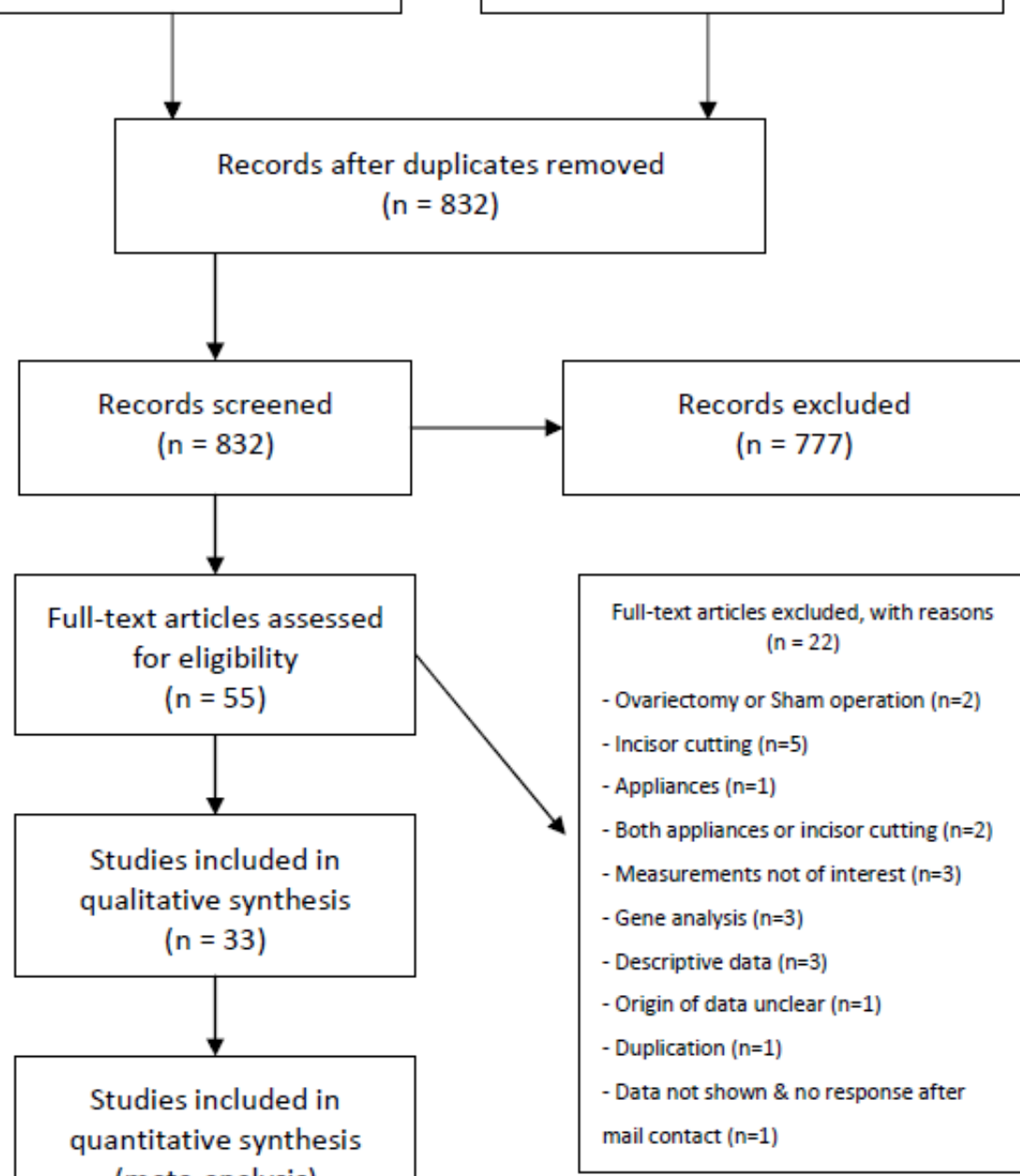

From: Moher D, Liberati A, Tetzlaff J, Altman DG, The PRISMA Group (2009). Preferred Reporting /tems for Systematic Reviews and MetaAnalyses: The PRISMA Statement. PLoS Med 6(7): e1000097. doi:10.1371/journal.pmed1000097 
Figure 2

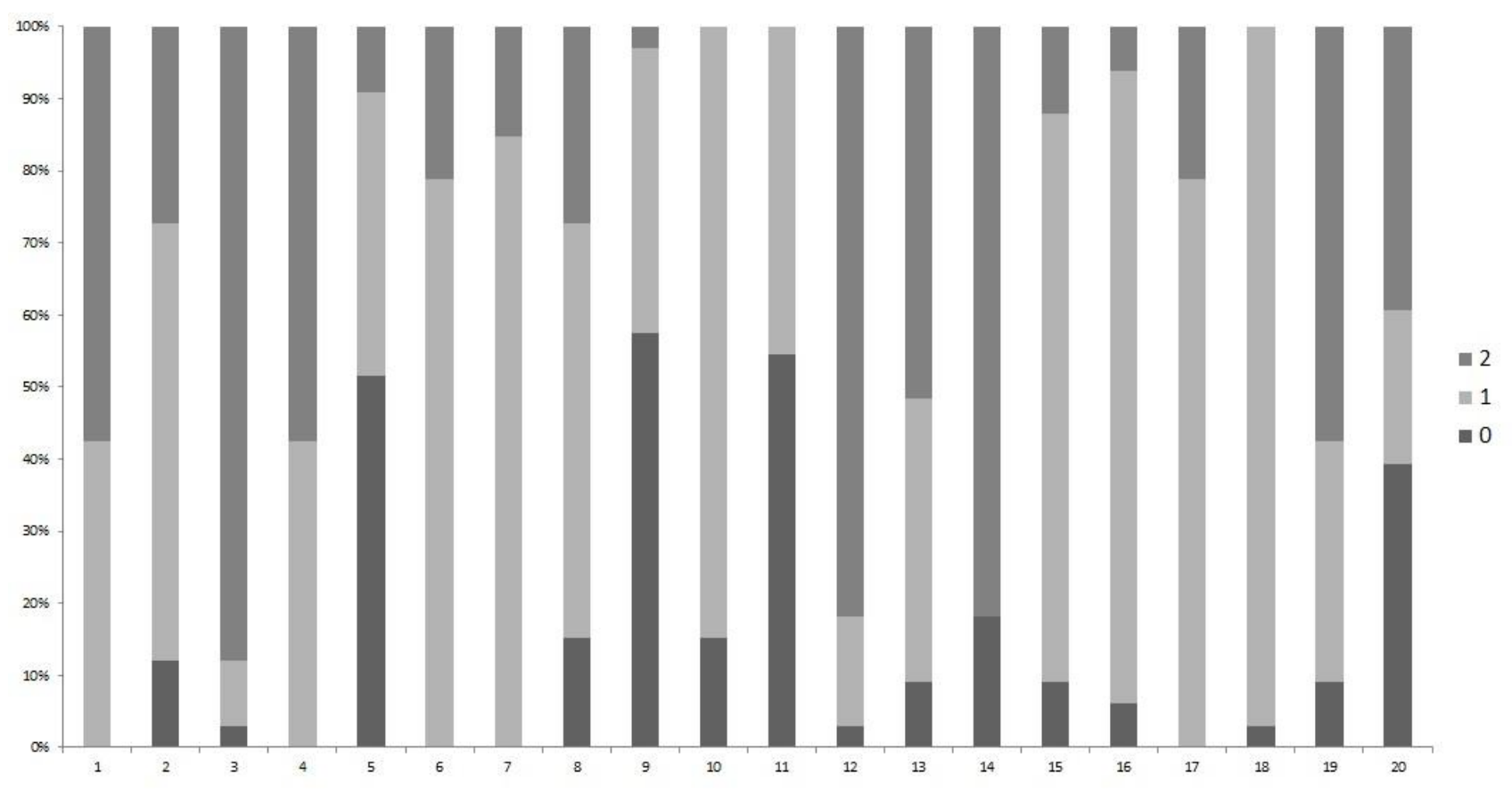




\section{Figure 3}

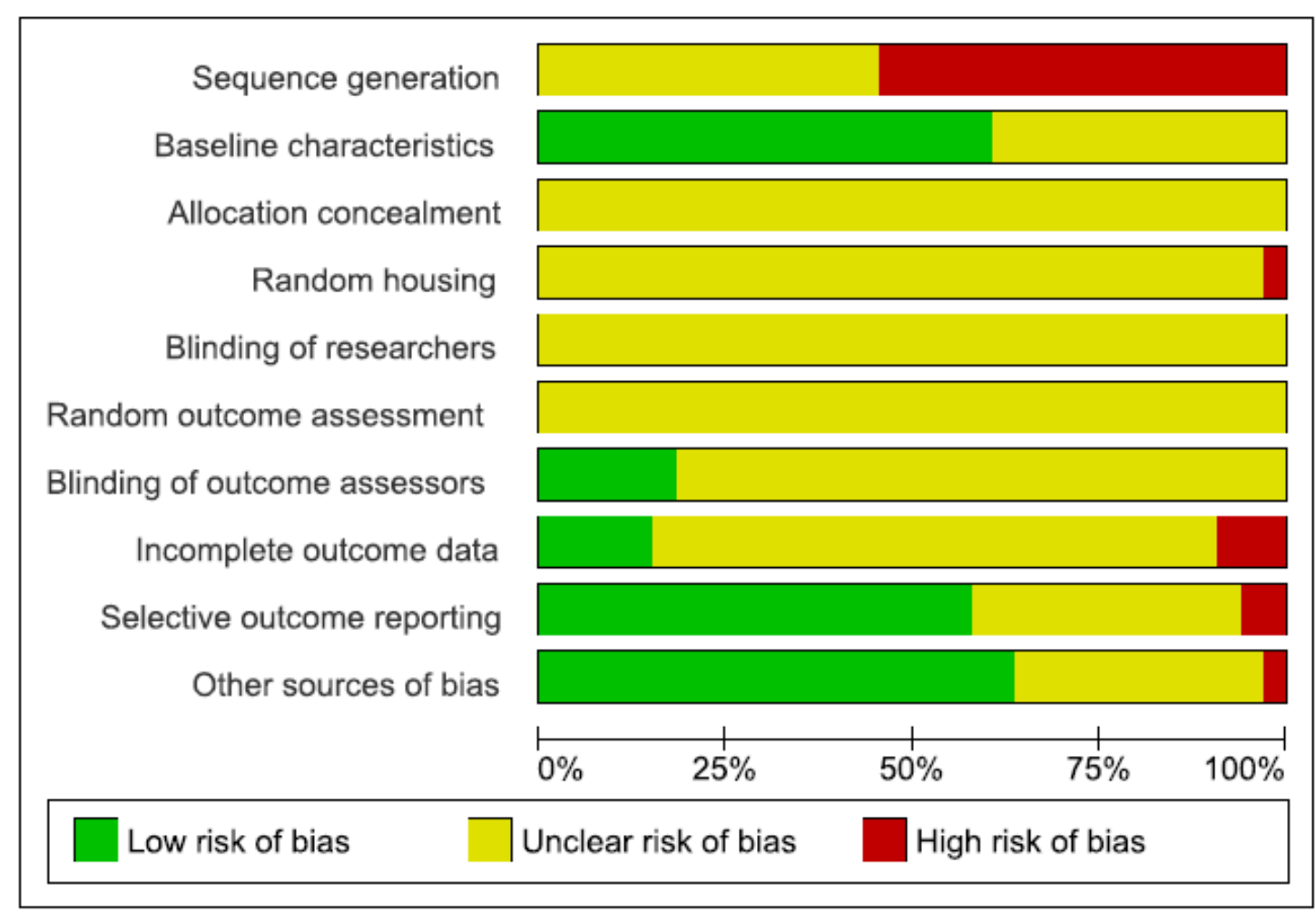


Figure 4

\begin{tabular}{|c|c|c|c|c|c|c|c|c|c|c|}
\hline & 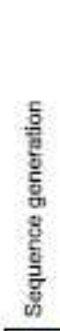 & 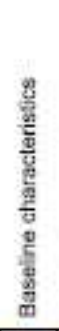 & 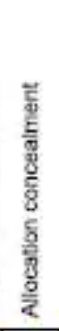 & 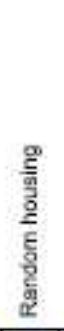 & 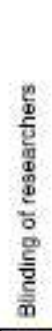 & 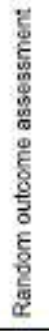 & 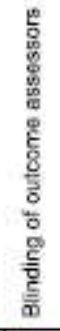 & 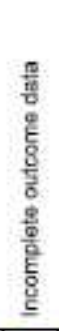 & 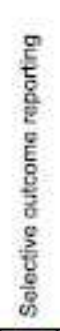 & 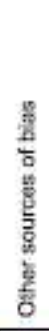 \\
\hline Abed 2007 & $?$ & (ㄷ) & $?$ & 3 & 3 & $?$ & (?) & 3 & 라 & (9) \\
\hline Barter 1963 & (?) & () & $?$ & $?$ & 7 & $?$ & 3 & (?) & 3 & $?$ \\
\hline Beecher \& Corruccini 1981 & e & 3 & 3 & 3 & ? & ? & e & 3 & () & ? \\
\hline Bouvies \& Hylander 1994 & ? & (ㄷ) & $?$ & 3 & $?$ & $?$ & (2) & 방 & 3 & (당 \\
\hline Bouvier \& Zimny 1987 & ? & 3 & 8 & 2 & ? & $?$ & $?$ & 3 & (ㄷ) & ? \\
\hline Bouvier 1988 & (-) & 3 & $?$ & $?$ & 3 & ? & 2 & () & (ㄷ) & $?$ \\
\hline Bresin 1994 & () & () & 3 & 2 & $?$ & $?$ & 3 & 3 & () & 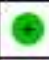 \\
\hline Bresin 1999 & ? & 3 & $?$ & $?$ & $?$ & $?$ & $?$ & 2 & $?$ & ? \\
\hline Endo 1998 & $?$ & 다 & 2 & 2 & 3 & $?$ & $?$ & 3 & () & $?$ \\
\hline Enomoto 2010 & 2 & 2 & $?$ & $?$ & 3 & 3 & $?$ & $?$ & $\odot$ & (당 \\
\hline Enomoto 2014 & 2 & () & $?$ & $?$ & $?$ & $?$ & $?$ & 3 & $?$ & 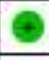 \\
\hline Guerteiro 2013 & 3 & (ㄷ) & $?$ & 3 & $?$ & ? & 3 & 궁 & 다 & 둥 \\
\hline Hichịo 2014 & $?$ & (ㄷ) & $?$ & $?$ & $?$ & $?$ & $?$ & $?$ & () & 웅 \\
\hline Hinton \& Cartson 1986 & 3 & 3 & $?$ & 3 & 3 & ? & 3 & ? & 라 & ? \\
\hline Ikeda 2014 & $?$ & 당 & $?$ & 3 & $?$ & (3) & 3 & 3 & ? & () \\
\hline the 1988 & ? & 낭 & 3 & $?$ & 3 & 3 & 3 & 3 & () & $?$ \\
\hline Kllanidis 1996 & e & () & $?$ & $?$ & 3 & $?$ & () & 3 & () & 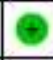 \\
\hline Kliaridis 1999 & 2 & 우 & $?$ & 3 & 2 & $?$ & $?$ & 3 & (ㄷ) & () \\
\hline Kingsmill 2010 & ? & 3 & $?$ & 3 & $?$ & ? & $?$ & () & $?$ & $\theta$ \\
\hline Maki 2002 & 2 & 2 & 2 & 2 & 0 & $?$ & $?$ & 2 & (ㄷ) & $?$ \\
\hline Mavropoulas 2010 & e & (†) & $?$ & 3 & $?$ & $?$ & 3 & $?$ & 3 & ()ㅜㅇ \\
\hline McFaddon 1996 & $?$ & () & $?$ & - & $?$ & $?$ & 3 & 3 & 다 & () \\
\hline Òdman 2000 & (2) & (ㄷ) & $?$ & 3 & $?$ & $?$ & $?$ & $?$ & () & (?) \\
\hline Orajajârvi 2011 & ? & 2 & 2 & 2 & 2 & $?$ & ? & 3 & $?$ & 2 \\
\hline Orajärvi 2012 & ? & $?$ & $?$ & 3 & 3 & ? & (룽 & 3 & 다 & 3 \\
\hline Orajārvi 2015 & (2) & $?$ & 3 & 8 & 8 & $?$ & () & 7 & (ㄷ) & 2 \\
\hline Shimizu 2013 & 2 & () & $?$ & 3 & 3 & $?$ & $?$ & 3 & 당 & $\theta$ \\
\hline Staht \& Dreizen 1984 & (2) & 다 & 2 & 2 & 3 & $?$ & $?$ & ? & 2 & 둥 \\
\hline Tanaka 2007 & ? & 다 & $?$ & $?$ & $?$ & $?$ & $?$ & $?$ & 3 & () \\
\hline TEkainen 2011 & (2) & 2 & 3 & 2 & 3 & $?$ & $?$ & $?$ & $?$ & $\odot$ \\
\hline Vaid 2002 & $?$ & 2 & 2 & 3 & $?$ & $?$ & $?$ & 3 & $?$ & $?$ \\
\hline Watt \& Williams 1951 & (2) & (당 & 3 & 2 & $?$ & 3 & $?$ & (ㄱ) & e & (9) \\
\hline Yamada \& Kimmol 1991 & (2) & 다 & 3 & 3 & $?$ & 3 & 3 & $?$ & $?$ & 당 \\
\hline
\end{tabular}


Figure 5

Study

ID

Kiliaridis et al., 1999
Bouvier 1988
Bouvier and Zimny, 1987
Bouvier and Hylander, 1984
Overall (I-squared $=0.0 \%, p=0.743)$
NOTE: Weights are from random effects analysis:

WMD $(95 \% \mathrm{Cl})$

Weight

$\%$

\section{Anteroposterior Condylar Length in Rats}


Figure 6

\section{Condylar Width in Rats}

Study

$\%$

ID

WMD $(95 \% \mathrm{Cl})$

Weight

Kiliaridis et al., 1999

Bouvier 1988

Bouvier and Zimny, 1987

Bouvier and Hylander, 1984

Overall (I-squared $=46.7 \%, p=0.131$ )

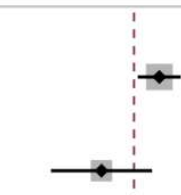

$-0.38(-0.42,-0.34)$

46.39

$-0.50(-0.60,-0.40) \quad 26.80$

$-0.50(-0.67,-0.33) \quad 15.12$

$-0.40(-0.60,-0.20) \quad 11.70$

$-0.43(-0.51,-0.36) \quad 100.00$

NOTE: Weights are from random effects analysis

$-.666$ 
Figure 7

Study

WMD $(95 \% \mathrm{Cl})$

Weight

Ito et al., 1988

Enomoto et al., 2009

Overall (I-squared $=0.0 \%, p=0.871)$

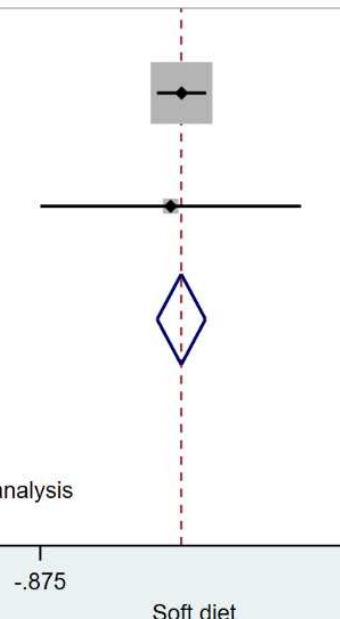

\begin{tabular}{cc}
$-0.49(-0.56,-0.42)$ & 96.57 \\
$-0.52(-0.87,-0.17)$ & 3.43 \\
& \\
$-0.49(-0.56,-0.43)$ & \\
& \\
\hline & \\
\hline & \\
\hline
\end{tabular}

NOTE: Weights are from random effects analysis

Soft diet

Hard diet 